\title{
The Isocaloric Substitution of Plant-Based and Animal-Based Protein in Relation to Aging-Related Health Outcomes: A Systematic Review
}

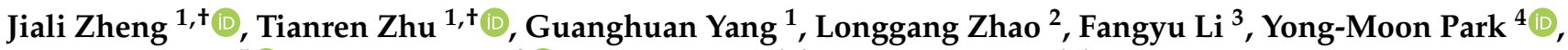 \\ Fred K. Tabung ${ }^{5}\left(\mathbb{D}\right.$, Susan E. Steck ${ }^{2} \mathbb{D}$, Xiaoguang $\mathrm{Li}^{1,6, *}$ and Hui Wang ${ }^{1,6, *}$
}

check for

updates

Citation: Zheng, J.; Zhu, T.; Yang, G.; Zhao, L.; Li, F.; Park, Y.-M.; Tabung, F.K.; Steck, S.E.; Li, X.; Wang, H. The Isocaloric Substitution of Plant-Based and Animal-Based Protein in Relation to Aging-Related Health Outcomes: A Systematic Review. Nutrients 2022, 14, 272. https:// doi.org/10.3390/nu14020272

Academic Editor: Sareen Gropper

Received: 16 November 2021

Accepted: 4 January 2022

Published: 9 January 2022

Publisher's Note: MDPI stays neutral with regard to jurisdictional claims in published maps and institutional affiliations.

Copyright: (c) 2022 by the authors. Licensee MDPI, Basel, Switzerland. This article is an open access article distributed under the terms and conditions of the Creative Commons Attribution (CC BY) license (https:// creativecommons.org/licenses/by/ $4.0 /)$.
1 School of Public Health, Shanghai Jiao Tong University School of Medicine, Shanghai 200025, China; jzheng@shsmu.edu.cn (J.Z.); marcus_zhu@sjtu.edu.cn (T.Z.); yangguanghuan1995@sjtu.edu.cn (G.Y.)

2 Department of Epidemiology and Biostatistics, Arnold School of Public Health, University of South Carolina, Columbia, SC 29208, USA; LZ7@email.sc.edu (L.Z.); stecks@mailbox.sc.edu (S.E.S.)

3 Department of Epidemiology, Division of Cancer Prevention and Population Sciences, The University of Texas MD Anderson Cancer Center, Houston, TX 77030, USA; Fangyu.Li@uth.tmc.edu

4 Department of Epidemiology, Fay W. Boozman College of Public Health, University of Arkansas for Medical Sciences, Little Rock, AR 72205, USA; YPark@uams.edu

5 Department of Internal Medicine, Division of Medical Oncology, The Ohio State University College of Medicine and Comprehensive Cancer Center, Columbus, OH 43210, USA; Fred.Tabung@osumc.edu

6 State Key Laboratory of Oncogenes and Related Genes, Center for Single-Cell Omics, School of Public Health, Shanghai Jiao Tong University School of Medicine, Shanghai 200025, China

* Correspondence: lixg@shsmu.edu.cn (X.L.); huiwang@shsmu.edu.cn (H.W.)

+ These authors contributed equally to this work.

\begin{abstract}
Plant-based and animal-based protein intake have differential effects on various agingrelated health outcomes, but less is known about the health effect of isocaloric substitution of plant-based and animal-based protein. This systematic review summarized current evidence of the isocaloric substitutional effect of plant-based and animal-based protein on aging-related health outcomes. PubMed and Embase databases were searched for epidemiologic observational studies published in English up to 15 March 2021. Studies that included adults $\geq 18$ years old; use of a nutritional substitution model to define isocaloric substitution of plant protein and animal protein; health outcomes covering mortality, aging-related diseases or indices; and reported association estimates with corresponding $95 \%$ confidence intervals were included. Nine cohort studies and 3 cross-sectional studies were identified, with a total of 1,450,178 subjects included in this review. Consistent and significant inverse association of substituting plant protein for various animal proteins on all-cause mortality was observed among 4 out of 5 studies with relative risks (RRs) from 0.54 to 0.95 and on cardiovascular disease (CVD) mortality among all 4 studies with RRs from 0.58 to 0.91 . Among specific animal proteins, the strongest inverse association on all-cause and CVD mortality was identified when substituting plant protein for red and/or processed meat protein, with the effect mainly limited to bread, cereal, and pasta protein when replacing red meat protein. Isocaloric substitution of plant-based protein for animal-based protein might prevent all-cause and CVD-specific mortality. More studies are needed on this topic, particularly for cancer incidence and other specific aging-related diseases.
\end{abstract}

Keywords: isocaloric substitution; animal protein; plant protein; aging; health outcomes; systematic review

\section{Introduction}

People worldwide are living longer, and the pace of aging is increasing dramatically. According to the World Health Organization, the proportion of the world's population over 60 years will nearly double from $12 \%$ in 2015 to $22 \%$ in 2050 , with an approximate 2 billion 
people aged 60 and above and 434 million people aged above 80 years by 2050 [1]. During aging, numerous physiological changes contribute to decreases in physical and mental capacity, immunity, and metabolism, which altogether lead to higher cardiometabolic risk and further increase the risk of aging-associated diseases such as cancer, cardiovascular disease (CVD), type-2 diabetes (T2D), chronic kidney disease, neurodegenerative disease, sarcopenia, frailty, and ultimately death [2-7].

As an essential macronutrient for humans, dietary protein plays a key role in maintaining physiological functioning and optimizing health span and longevity, mainly because of its favorable effect on weight management, strength, and maintaining cardiometabolic profile [8-11]. In regard to the health effect of protein intake, substantial evidence has suggested that the source of protein and not only the amount of protein is important. Previous reviews reached the conclusion that animal-based and plant-based protein had differential health effects: higher consumption of animal-based protein and major contributing food sources such as red and/or processed meat were associated with increased risk of cardiometabolic markers [12], weight gain [13], CVD [14-17], kidney diseases [18], gastrointestinal cancers [19], T2D [20,21], and all-cause mortality [22], while higher intake of plant protein was linked to decreased risk of several aging-related outcomes including metabolic syndrome and its risk factors, T2D, cancer, CVD mortality, and all-cause mortality [17,20,23-27].

Individuals tend to keep daily calorie intake constant under normal health status; thus, it is important to acknowledge that the effect of an increased intake of a macronutrient on a given health outcome is countered by reduced energy intake of another macronutrient (i.e., a substitution effect). Theoretically, this isocaloric substitutional effect can be statistically estimated in the nutritional substitution model while leaving out the replaced macronutrient but including other macronutrients and total energy in the model [28]. Substitution analysis for plant- and animal-based protein may thus have an advantage over studies investigating the independent effect of protein intake as the substitution analysis may differentiate the health effects of these two major protein sources, and further help to identify and inform the optimal protein source for health promotion and disease prevention.

Recently, several studies were published on the topic of isocaloric substitution of animaland plant-based protein on a wide array of aging-related health outcomes [7,10,29-38]. However, summary evidence on this topic is lacking. Therefore, we conducted this review to add new evidence in the literature by comprehensively summarizing the current evidence of the isocaloric substitutional effects of animal- and plant-based protein on various aging-related outcomes.

\section{Materials and Methods}

This systematic review was conducted and reported according to the PRISMA (Preferred Reporting Items for Systematic Reviews and Meta-Analyses) guidelines [39]. This review was registered with the International Prospective Register of Systematic Reviews (PROSPERO identifier: CRD 42021258075).

\subsection{Search Strategy}

A comprehensive literature search of epidemiological observational studies on the association between isocaloric substitution of plant-based and animal-based protein and aging-related health outcomes was conducted using the PubMed and Embase databases. Each search term related to dietary plant or animal protein intake ("protein intake", "dietary protein", "animal-based protein", "animal protein", "plant-based protein", "plant protein", "protein source", "food source", "food", "diet") in combination with each term associated with isocaloric substitution ("substitution", "substitute", "replace", "replacement", "alternative", "isocaloric", "isoenergetic") was searched using an "AND" command in two databases. The search was restricted to human studies published up to 15 March 2021 in English. Due to the broad scope of aging-related diseases, we did not restrict outcomes in the search phase. 


\subsection{Eligibility Criteria}

Studies that met the following PICOS (Population, Intervention, Comparison, Outcomes, Study design) criteria were included in this systematic review (Table 1): (1) crosssectional, case-control, or cohort study as study design; (2) studies were conducted in the adult population aged over 18 years; (3) the nutritional substitution model with the replaced protein left out of the model but the other macronutrients and total energy included was clearly demonstrated; (4) isocaloric substitution of plant-based protein intake (or plant-based protein from specific food sources) for animal-based protein intake (or animal-based protein from specific food sources) was described as the exposure; (5) agingrelated health outcomes including all-cause and cause-specific mortality, cancers, CVD, cerebral diseases, cognitive impairment, chronic kidney disease, respiratory diseases, risk markers of metabolic diseases and aging-related indices were described as study outcomes; and (6) studies provided odds ratios (ORs), hazard ratios (HRs), prevalence ratios (PRs) or relative risks (RRs) with corresponding standard errors or $95 \%$ confidence intervals (CIs). Clinical trials were excluded in this review because the substitutional effects were observed in an interventional approach in clinical trials while it was generated from an ideal and theoretical model-based approach in observational studies. If the substitutional associations were obtained only based on combined data from pooling cohorts or results from meta-analysis of several separate cohorts without estimates from individual studies, we treated this as one study. References from identified publications or relevant reviews were also searched to identify additional eligible studies.

Table 1. Population, Intervention, Comparison, Outcomes, Study (PICOS) criteria for inclusion of studies.

\begin{tabular}{cc}
\hline Parameter & Inclusion Criteria \\
\hline Population & $\begin{array}{c}\text { Adults aged over 18 (including mean age) at } \\
\text { baseline for cohort studies }\end{array}$ \\
\hline Intervention/exposure & $\begin{array}{c}\text { Isocaloric substitution of plant-based and } \\
\text { animal-based protein or protein from food } \\
\text { sources, as defined in the context of nutritional } \\
\text { substitution model }\end{array}$ \\
Comparison & $\begin{array}{c}\text { Continuous (e.g., } 3 \% \text { or } 5 \% \text { of total energy from } \\
\text { plant protein substituted for animal protein) or } \\
\text { categorical (e.g., highest vs. lowest level of } \\
\text { percentage of energy from plant protein } \\
\text { substituted for animal protein) }\end{array}$ \\
\hline Outcomes & $\begin{array}{c}\text { Aging-related health outcomes which included } \\
\text { mortality outcomes, aging-related disorders } \\
\text { such as cancer, type-2 diabetes, chronic kidney } \\
\text { diseases, cardiometabolic diseases and risk } \\
\text { markers, as well as aging-related indices }\end{array}$ \\
\hline Study design & $\begin{array}{c}\text { Original research studies of any observational } \\
\text { design were eligible. Systematic or narrative } \\
\text { reviews, intervention studies, conference or } \\
\text { dissertations, editorials, case reports or other } \\
\text { descriptive studies were excluded }\end{array}$ \\
\hline
\end{tabular}

\subsection{Study Selection and Data Extraction}

Two authors (T.Z. and G.Y.) independently searched the literature and selected the eligible studies based on prespecified inclusion criteria. The study selection process is shown in Figure 1. The following important characteristics from the included studies were extracted into Table 2: reference of the publication (name of the first author and year of publication); study design and study location; number of cases and total participants at risk; mean age or age range of baseline study population; mean or median follow-up time for 
cohort studies; characteristics of dietary exposure; the substitution model; study outcome; and variables from the most fully-adjusted model. We described the substitutional effect of animal protein for plant protein or plant protein for animal protein separately and specified the food sources of protein for studies describing replacement of protein from food sources. For the substitution model, we described the type (continuous or categorical) and unit (e.g., percentage of total energy) of the substituted exposure and the other macronutrients and total energy that were held constant in the model. Forest plots were used to show the point estimates (e.g., RR, PR, HR, OR) and 95\% CIs of each reported substitutional association of animal-based and plant-based protein with aging-related disease mortality risk or associations with disease incidence/prevalence risk based on the findings from the most fully adjusted model, along with the $P$-trend value for the highest versus lowest category of the substituted exposure if available. Sex-specific associations were also displayed if they were presented in the original studies. In each forest plot, associations were listed by outcomes from an overall disease to its subtypes (e.g., CVD overall and specific CVD disease such as stroke). For the same outcome, exposures were arranged from substitution of total plant protein for total animal protein and next, substitution of total plant protein for specific animal proteins, followed by specific plant proteins replacing specific animal proteins. A meta-analysis was not conducted in the current review because of the small number of studies on the exact same exposure of substitution (i.e., same specific animal and plant protein for substitution) and the same aging-related outcome. All forest plots were drawn using $R$ software (R 3.6.3).

Records identified through PubMed $(n=1028)$ and Embase $(n=1053)$

Duplicate records removed $(n=259)$

references and reviews $(n=5)$

Full-text articles assessed for eligibility $(n=103)$

Record excluded based on the following reasons ( $n=1724)$

1. Non-English studies $(n=47)$

2. Non-human studies $(n=960)$

3. Letters, comments, editorials, randomized, controlled

trials, reviews, and meta-analyses $(n=383)$

4. Topics irrelevant to dietary protein intake $(n=334)$

Full-text articles were excluded because of the following

reasons $(n=91)$

Studies did not report substitutional effects of

animal-based and plant-based proteins $(n=86)$

2. Point estimates and $95 \%$ confidence intervals were absent

$(n=2)$

3. The study outcome was not an aging-related outcome

$(n=1)$

4. The information provided in the substitution mode

was not clear $(n=1)$

5. The study population was under 18 years old $(n=1)$

Studies included in the systematic review $(n=12$

Figure 1. Flow diagram of literature search process. 
Table 2. Summary characteristics of included studies on the association between isocaloric substitutional effect of animal-based and plant-based protein and aging-related health outcomes $(N=12)$.

\begin{tabular}{|c|c|c|c|c|c|c|c|c|}
\hline Reference & $\begin{array}{l}\text { Study Design } \\
\text { (Location) }\end{array}$ & $\begin{array}{c}\text { Number of } \\
\text { Cases }{ }^{\mathrm{a} / T o t a l} \\
\text { Individuals at } \\
\text { Risk }^{\mathrm{b}}\end{array}$ & Mean Age (Range) & $\begin{array}{l}\text { Mean or } \\
\text { Median } \\
\text { Follow-Up } \\
\text { Time for } \\
\text { Cohort Study }\end{array}$ & $\begin{array}{l}\text { Diet Assessment } \\
\text { Instru- } \\
\text { ment/Assessment } \\
\text { Period/Whether } \\
\text { Assessment of } \\
\text { Validity and } \\
\text { Reproducibility }\end{array}$ & Substitutional Model & $\begin{array}{l}\text { Aging-Related } \\
\text { Outcomes }\end{array}$ & Variables for Adjustment ${ }^{c}$ \\
\hline $\begin{array}{l}\text { Kelemen et al. } \\
\text { (2004) [31] }\end{array}$ & $\begin{array}{l}\text { Cohort study } \\
\text { (USA) }\end{array}$ & $\begin{array}{l}4843 \text { total incident } \\
\text { cancer cases and } \\
3978 \text { total } \\
\text { deaths/29,017 } \\
\text { participants }\end{array}$ & $55-69$ & $\begin{array}{l}\text { Mean }=11.4 \\
\text { years }\end{array}$ & $\begin{array}{c}\text { 131-item } \\
\text { self-administered } \\
\text { FFQ/in the past } \\
\text { year/validity and } \\
\text { reproducibility were } \\
\text { both assessed }\end{array}$ & $\begin{array}{l}\text { Highest versus lowest } \\
\text { quintile of percentage of } \\
\text { energy from total plant } \\
\text { protein substituted for total } \\
\text { animal protein while holding } \\
\text { constant the intake of total } \\
\text { energy, carbohydrate and fat }\end{array}$ & $\begin{array}{l}\text { 1. Mortality from the } \\
\text { following causes: } \\
\text { all-cause, CHD, total } \\
\text { cancer; } \\
\text { 2. Total cancer } \\
\text { incidence }\end{array}$ & $\begin{array}{l}\text { Age, total energy, carbohydrate, } \\
\text { saturated fat, polyunsaturated } \\
\text { fat, monounsaturated fat, } \\
\text { trans-fat, total fiber, dietary } \\
\text { cholesterol, dietary methionine, } \\
\text { alcohol drink, smoking status, } \\
\text { activity level, BMI, history of } \\
\text { hypertension, postmenopausal } \\
\text { hormone use, multivitamin use, } \\
\text { vitamin E supplement use, } \\
\text { education, and family history } \\
\text { of cancer }\end{array}$ \\
\hline $\begin{array}{l}\text { der Kuil et al. } \\
\text { (2013) [37] }\end{array}$ & $\begin{array}{l}\text { Cohort study } \\
\text { (16 European } \\
\text { countries) }\end{array}$ & $\begin{array}{c}298 \text { incident } \\
\text { hypertension } \\
\text { cases } / 1319 \\
\text { participants with } \\
\text { type-1 DM } \\
135 \text { incident } \\
\text { microalbuminuria } \\
\text { cases } / 1045 \\
\text { participants with } \\
\text { type-1 DM }\end{array}$ & $31.0(15-60)$ & $\begin{array}{l}\text { Mean }=7 \\
\text { years }\end{array}$ & $\begin{array}{l}\text { 3-day food } \\
\text { record/within a } \\
\text { 2-week period at } \\
\text { baseline/NA }\end{array}$ & $\begin{array}{l}\text { 1.Substitution of } 3 \% \text { of } \\
\text { energy intake form total } \\
\text { animal protein for total plant } \\
\text { protein holding constant the } \\
\text { intake of total energy, } \\
\text { carbohydrate and fat; } \\
\text { 2. Substitution of } 3 \% \text { of } \\
\text { energy intake from total } \\
\text { plant protein for total animal } \\
\text { protein holding constant the } \\
\text { intake of total energy, } \\
\text { carbohydrate and fat }\end{array}$ & $\begin{array}{l}\text { Hypertension and } \\
\text { microalbuminuria } \\
\text { incidence }\end{array}$ & $\begin{array}{l}\text { Age, sex, diabetes duration, } \\
\text { HbA1c, BMI, smoking status, } \\
\text { physical activity, total energy } \\
\text { intake, energy densities from } \\
\text { fat, carbohydrate and alcohol }\end{array}$ \\
\hline
\end{tabular}


Table 2. Cont.

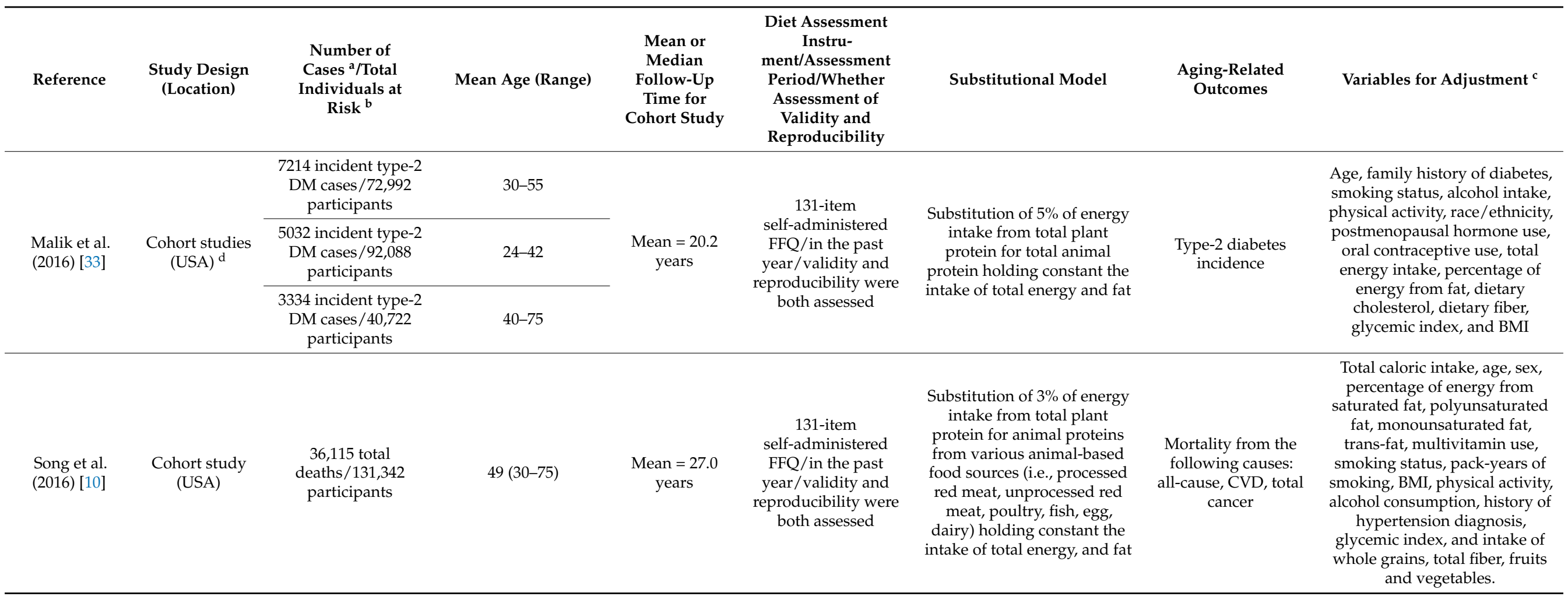


Table 2. Cont.

\begin{tabular}{|c|c|c|c|c|c|c|c|c|}
\hline Reference & $\begin{array}{l}\text { Study Design } \\
\text { (Location) }\end{array}$ & $\begin{array}{c}\text { Number of } \\
\text { Cases }{ }^{\mathrm{a} / T o t a l} \\
\text { Individuals at } \\
\text { Risk }^{\mathrm{b}}\end{array}$ & Mean Age (Range) & $\begin{array}{l}\text { Mean or } \\
\text { Median } \\
\text { Follow-Up } \\
\text { Time for } \\
\text { Cohort Study }\end{array}$ & $\begin{array}{l}\text { Diet Assessment } \\
\text { Instru- } \\
\text { ment/Assessment } \\
\text { Period/Whether } \\
\text { Assessment of } \\
\text { Validity and } \\
\text { Reproducibility }\end{array}$ & Substitutional Model & $\begin{array}{l}\text { Aging-Related } \\
\text { Outcomes }\end{array}$ & Variables for Adjustment ${ }^{c}$ \\
\hline $\begin{array}{l}\text { Van Baak et al. } \\
\text { (2017) [36] }\end{array}$ & $\begin{array}{l}\text { Cross- } \\
\text { sectional study } \\
\text { (8 European } \\
\text { countries) }\end{array}$ & $\begin{array}{l}489 \text { overweight or } \\
\text { obese participants }\end{array}$ & $42.3(<65)$ & NA & $\begin{array}{c}\text { 3-day food } \\
\text { record/Four weeks } \\
\text { after the start of WM } \\
\text { phase and in the last } \\
\text { week of WM phase } \\
\text { e /NA }\end{array}$ & $\begin{array}{l}\text { Substitution of } 1 \% \text { of total } \\
\text { protein intake from total } \\
\text { animal protein for total plant } \\
\text { protein holding constant the } \\
\text { intake of total protein }\end{array}$ & $\begin{array}{l}\text { Change in body } \\
\text { weight, body fat, } \\
\text { waist circumference, } \\
\text { SBP, DBP, total } \\
\text { cholesterol, HDL-C, } \\
\text { LDL-C, triglycerides, } \\
\text { fasting glucose, } \\
\text { fasting insulin, } \\
\text { HOMA-IR, matsuda } \\
\text { index, CRP, } \\
\text { adiponectin during } \\
\text { the WM phase }\end{array}$ & $\begin{array}{l}\text { BMI at randomization, changes } \\
\text { in the anthropometrics, blood } \\
\text { pressure and metabolic } \\
\text { parameters during the weight } \\
\text { loss phase, gender, type of } \\
\text { center, dietary protein intake, } \\
\text { glycemic index, dietary fat } \\
\text { intake and fiber intake }\end{array}$ \\
\hline $\begin{array}{c}\text { Budhathoki } \\
\text { et al. (2019) } \\
\text { [29] }\end{array}$ & $\begin{array}{l}\text { Cohort study } \\
\text { (Japan) }\end{array}$ & $\begin{array}{c}12,381 \text { total } \\
\text { deaths } / 70,696 \\
\text { participants }\end{array}$ & $55.7(45-74)$ & $\begin{array}{l}\text { Mean }=18 \\
\text { years }\end{array}$ & $\begin{array}{c}\text { 138-item } \\
\text { self-administered } \\
\text { FFQ/in the past } \\
\text { year/validity and } \\
\text { reproducibility were } \\
\text { both assessed }\end{array}$ & $\begin{array}{l}\text { Substitution of } 3 \% \text { of energy } \\
\text { intake from total plant } \\
\text { protein for animal proteins } \\
\text { from various animal-based } \\
\text { food sources (i.e., red meat, } \\
\text { processed meat, chicken, egg, } \\
\text { dairy, fish) holding constant } \\
\text { the intake of total energy, } \\
\text { carbohydrate and fat }\end{array}$ & $\begin{array}{l}\text { Mortality from the } \\
\text { following causes: } \\
\text { all-cause, CVD, total } \\
\text { cancer }\end{array}$ & $\begin{array}{l}\text { Total energy, percentage of } \\
\text { energy from fats and } \\
\text { carbohydrates, age, sex, BMI, } \\
\text { smoking status, alcohol use, } \\
\text { physical activity, occupation } \\
\text { status, and intake of green tea } \\
\text { and coffee. }\end{array}$ \\
\hline
\end{tabular}


Table 2. Cont.

\begin{tabular}{|c|c|c|c|c|c|c|c|c|}
\hline Reference & $\begin{array}{l}\text { Study Design } \\
\text { (Location) }\end{array}$ & $\begin{array}{c}\text { Number of } \\
\text { Cases a/Total } \\
\text { Individuals at } \\
\text { Risk }^{b}\end{array}$ & Mean Age (Range) & $\begin{array}{l}\text { Mean or } \\
\text { Median } \\
\text { Follow-Up } \\
\text { Time for } \\
\text { Cohort Study }\end{array}$ & $\begin{array}{l}\text { Diet Assessment } \\
\text { Instru- } \\
\text { ment/Assessment } \\
\text { Period/Whether } \\
\text { Assessment of } \\
\text { Validity and } \\
\text { Reproducibility }\end{array}$ & Substitutional Model & $\begin{array}{l}\text { Aging-Related } \\
\text { Outcomes }\end{array}$ & Variables for Adjustment ${ }^{c}$ \\
\hline $\begin{array}{l}\text { Liao et al. } \\
\text { (2019) [32] }\end{array}$ & $\begin{array}{l}\text { Cohort study } \\
\text { (USA) }\end{array}$ & $\begin{array}{l}8995 \text { incident } \\
\text { colorectal cancer } \\
\text { cases } / 489,625 \\
\text { participants }\end{array}$ & $50-71$ & $\begin{array}{l}\text { Median }=15.5 \\
\text { years }\end{array}$ & $\begin{array}{c}\text { 124-item } \\
\text { self-administered } \\
\text { FFQ/in the past } \\
\text { year/validity and } \\
\text { reproducibility were } \\
\text { both assessed }\end{array}$ & $\begin{array}{l}\text { 1. Highest versus lowest } \\
\text { quintile of amount of total } \\
\text { plant protein substituted for } \\
\text { animal protein from various } \\
\text { animal-based food sources } \\
\text { (all animal foods, red meat, } \\
\text { white meat, other animal } \\
\text { foods) holding constant the } \\
\text { intake of total energy and } \\
\text { protein; } \\
\text { 2. Highest versus lowest } \\
\text { quintile of amount of plant } \\
\text { protein from various } \\
\text { plant-based food sources } \\
\text { (bread, cereal and pasta; nuts; } \\
\text { beans and legumes; other } \\
\text { plant sources) substituted for } \\
\text { red meat protein holding } \\
\text { constant the intake of total } \\
\text { energy and protein }\end{array}$ & $\begin{array}{l}\text { Colorectal cancer, } \\
\text { colon cancer, } \\
\text { proximal colon } \\
\text { cancer, distal colon } \\
\text { cancer, and rectal } \\
\text { cancer incidence }\end{array}$ & $\begin{array}{l}\text { Age, total protein, total energy, } \\
\text { sex, education, marriage status, } \\
\text { family history of colon cancer, } \\
\text { race, BMI, smoking status, } \\
\text { frequency of vigorous physical } \\
\text { activity, alcohol intake, fruit } \\
\text { intake, vegetable intake, total } \\
\text { calcium intake, total folate } \\
\text { intake, dietary fiber intake. }\end{array}$ \\
\hline $\begin{array}{c}\text { Oosterwijk } \\
\text { et al. (2019) } \\
\text { [38] }\end{array}$ & $\begin{array}{l}\text { Cross- } \\
\text { sectional study } \\
\text { (Netherland) }\end{array}$ & $\begin{array}{l}99 \text { renal function } \\
\text { impairment } \\
\text { cases } / 420 \\
\text { participants with } \\
\text { type-2 DM }\end{array}$ & 63 & NA & $\begin{array}{c}\text { 177-item } \\
\text { self-administered } \\
\text { FFQ/in the past } \\
\text { month/only validity } \\
\text { was assessed }\end{array}$ & $\begin{array}{l}\text { 1. Substitution of } 3 \% \text { of } \\
\text { energy intake from total } \\
\text { plant protein for total animal } \\
\text { protein holding constant the } \\
\text { intake of total energy, fat and } \\
\text { carbohydrate; } \\
\text { 2. Substitution of } 3 \% \text { of } \\
\text { energy intake from total } \\
\text { animal protein for total plant } \\
\text { protein holding constant the } \\
\text { intake of total energy, fat and } \\
\text { carbohydrate. }\end{array}$ & $\begin{array}{l}\text { Renal function } \\
\text { impairment } \\
\text { prevalence }\end{array}$ & $\begin{array}{l}\text { Age, gender, diabetes duration, } \\
\text { BMI, smoking status, physical } \\
\text { activity, alcohol intake, } \\
\text { saturated fat intake, } \\
\text { unsaturated fat intake, intake } \\
\text { of mono- and disaccharides, } \\
\text { intake of polysaccharides, } \\
\text { intake of fiber and intake of } \\
\text { trans fatty acids. }\end{array}$ \\
\hline
\end{tabular}


Table 2. Cont.

\begin{tabular}{|c|c|c|c|c|c|c|c|c|}
\hline Reference & $\begin{array}{l}\text { Study Design } \\
\text { (Location) }\end{array}$ & $\begin{array}{c}\text { Number of } \\
\text { Cases a/Total } \\
\text { Individuals at } \\
\text { Risk }^{b}\end{array}$ & Mean Age (Range) & $\begin{array}{l}\text { Mean or } \\
\text { Median } \\
\text { Follow-Up } \\
\text { Time for } \\
\text { Cohort Study }\end{array}$ & $\begin{array}{l}\text { Diet Assessment } \\
\text { Instru- } \\
\text { ment/Assessment } \\
\text { Period/Whether } \\
\text { Assessment of } \\
\text { Validity and } \\
\text { Reproducibility }\end{array}$ & Substitutional Model & $\begin{array}{l}\text { Aging-Related } \\
\text { Outcomes }\end{array}$ & Variables for Adjustment ${ }^{c}$ \\
\hline $\begin{array}{l}\text { Huang et al. } \\
\text { (2020) [30] }\end{array}$ & $\begin{array}{l}\text { Cohort study } \\
\text { (USA) }\end{array}$ & $\begin{array}{c}77,614 \text { total } \\
\text { deaths/416,104 } \\
\text { participants }\end{array}$ & $62.1(50-71)$ & $\begin{array}{l}\text { Median }=15.5 \\
\text { years }\end{array}$ & $\begin{array}{c}\text { 124-item } \\
\text { self-administered } \\
\text { FFQ/in the past } \\
\text { year/validity and } \\
\text { reproducibility were } \\
\text { both assessed }\end{array}$ & $\begin{array}{l}\text { 1. Substitution of } 3 \% \text { of } \\
\text { energy from total plant } \\
\text { protein for animal proteins } \\
\text { from various animal-based } \\
\text { food sources (all animal } \\
\text { foods, red meat, white meat, } \\
\text { dairy, egg) holding constant } \\
\text { the intake of total energy and } \\
\text { fat; } \\
\text { 2. Substitution of } 3 \% \text { of } \\
\text { energy from plant protein } \\
\text { from various plant-based } \\
\text { food sources (bread, cereal } \\
\text { and pasta; nuts; beans and } \\
\text { legumes; other plant foods) } \\
\text { for egg and red meat protein } \\
\text { holding constant the intake } \\
\text { of total energy and fat. }\end{array}$ & $\begin{array}{l}\text { Mortality from the } \\
\text { following causes: } \\
\text { all-cause, CVD, total } \\
\text { cancer, heart disease, } \\
\text { stroke, respiratory } \\
\text { disease }\end{array}$ & $\begin{array}{l}\text { Age at entry, BMI, alcohol } \\
\text { consumption, smoking status, } \\
\text { physical activity, race or ethnic } \\
\text { group, educational level, } \\
\text { marital status, diabetes, health } \\
\text { status, vitamin supplement use, } \\
\text { daily dietary total energy, } \\
\text { animal protein, saturated fat, } \\
\text { polyunsaturated fat, } \\
\text { monounsaturated fat, trans fat, } \\
\text { fiber, vegetables, and fruits, } \\
\text { and postmenopausal hormone } \\
\text { replacement therapy. }\end{array}$ \\
\hline $\begin{array}{l}\text { Ortolá et al. } \\
\text { (2020) [7] }\end{array}$ & $\begin{array}{l}\text { Cohort study } \\
\text { (Spain) }\end{array}$ & 812 participants & $68.6(>60)$ & $\begin{array}{l}\text { Median }=8.2 \\
\quad \text { years }\end{array}$ & $\begin{array}{c}900 \text {-item } \\
\text { computerized diet } \\
\text { history/in the past } \\
\text { year/ only validity } \\
\text { was assessed }\end{array}$ & $\begin{array}{l}1 \% \text { change in energy from } \\
\text { total plant protein } \\
\text { substituted for animal } \\
\text { protein from various } \\
\text { animal-based sources (total } \\
\text { animal foods, dairy, meat, } \\
\text { egg and fish) from wave } 0 \\
\text { (2008-2010) to wave } 1 \text { (2012) } \\
\text { holding constant the intake } \\
\text { of total energy, carbohydrate } \\
\text { and fat }\end{array}$ & $\begin{array}{l}\text { Change in DAI } \\
\text { between wave } 0 \\
(2008-2010) \text { and } \\
\text { wave } 3(2017)^{\mathrm{f}}\end{array}$ & $\begin{array}{l}\text { Sex, age, educational level, DAI } \\
\text { at wave } 0 \text {, changes in energy } \\
\text { intake, vegetable protein intake, } \\
\text { animal protein intake from all } \\
\text { sources except the one being } \\
\text { examined, fat intake, } \\
\text { carbohydrate intake and } \\
\text { alcohol intake from wave } 0 \text { to } \\
\text { wave } 1 \text {, changes in smoking } \\
\text { status, alcohol consumption } \\
\text { status, leisure-time physical } \\
\text { activity, sedentary behavior, } \\
\text { and BMI from wave } 0 \text { to wave } \\
3 \text {. }\end{array}$ \\
\hline
\end{tabular}


Table 2. Cont.

\begin{tabular}{|c|c|c|c|c|c|c|c|c|}
\hline Reference & $\begin{array}{l}\text { Study Design } \\
\text { (Location) }\end{array}$ & $\begin{array}{c}\text { Number of } \\
\text { Cases a/Total } \\
\text { Individuals at } \\
\text { Risk }^{b}\end{array}$ & Mean Age (Range) & $\begin{array}{l}\text { Mean or } \\
\text { Median } \\
\text { Follow-Up } \\
\text { Time for } \\
\text { Cohort Study }\end{array}$ & $\begin{array}{l}\text { Diet Assessment } \\
\text { Instru- } \\
\text { ment/Assessment } \\
\text { Period/Whether } \\
\text { Assessment of } \\
\text { Validity and } \\
\text { Reproducibility }\end{array}$ & Substitutional Model & $\begin{array}{l}\text { Aging-Related } \\
\text { Outcomes }\end{array}$ & Variables for Adjustment ${ }^{c}$ \\
\hline $\begin{array}{l}\text { Montiel-Rojas } \\
\text { et al. (2020) } \\
{[34]}\end{array}$ & $\begin{array}{l}\text { Cross- } \\
\text { sectional study } \\
\text { (4 European } \\
\text { countries })\end{array}$ & 986 participants & $65-79$ & NA & $\begin{array}{c}\text { 1-week food } \\
\text { record/at baseline/ } \\
\text { NA }\end{array}$ & $\begin{array}{l}\text { Substitution of } 0.1 \mathrm{~g} / \mathrm{BW} \\
\text { increase of total plant protein } \\
\text { for total animal protein } \\
\text { holding constant the intake } \\
\text { of total energy and protein }\end{array}$ & $\begin{array}{l}\text { Sarcopenia risk } \\
\text { score } \mathrm{g}\end{array}$ & $\begin{array}{l}\text { Total protein intake, plant } \\
\text { protein intake, total energy } \\
\text { intake, age, recruiting center, } \\
\text { medication, smoking habits, } \\
\text { prevalence of MetS, adherence } \\
\text { to PA guidelines, and fiber } \\
\text { intake. }\end{array}$ \\
\hline $\begin{array}{l}\text { Sun et al. } \\
\text { (2021) [35] }\end{array}$ & $\begin{array}{l}\text { Cohort study } \\
\text { (USA) }\end{array}$ & $\begin{array}{c}25,976 \text { total } \\
\text { deaths } / 102,521 \\
\text { participants }\end{array}$ & $50-79$ & $\begin{array}{l}\text { Mean }=18.1 \\
\text { years }\end{array}$ & $\begin{array}{l}\text { 122-item } \\
\text { self-administered } \\
\text { FFQ/in the past } \\
\text { three } \\
\text { months/validity and } \\
\text { reproducibility were } \\
\text { both assessed }\end{array}$ & $\begin{array}{l}\text { Substitution of } 5 \% \text { of energy } \\
\text { from total plant protein for } \\
\text { total animal protein holding } \\
\text { constant the intake of total } \\
\text { energy and fat }\end{array}$ & $\begin{array}{l}\text { Mortality from the } \\
\text { following causes: } \\
\text { all-cause, CVD, total } \\
\text { cancer, dementia }\end{array}$ & $\begin{array}{c}\text { Age at baseline, race/ethnicity, } \\
\text { education, income, } \\
\text { Observational Study/Clinical } \\
\text { Trials, hormone use history, } \\
\text { smoking status, physical } \\
\text { activity, baseline diabetes } \\
\text { mellitus status and high blood } \\
\text { cholesterol status, and family } \\
\text { history of heart attack/stroke, } \\
\text { alcohol intake, total energy } \\
\text { intake, percentage of energy } \\
\text { from saturated fatty acids, } \\
\text { polyunsaturated fatty acids, } \\
\text { monounsaturated fatty acids } \\
\text { and trans-fatty acids, dietary } \\
\text { fiber intake, and glycemic load. }\end{array}$ \\
\hline
\end{tabular}

Abbreviations: BMI: body mass index; BW: body weight; CHD: coronary heart disease; CRP: C-reactive protein; CVD: cardiovascular diseases; DAI: deficit accumulation index; DBP: diastolic blood pressure; FFQ: food frequency questionnaire; HDL-C: high-density lipoprotein cholesterol; HOMA-IR: Homeostatic Model Assessment for Insulin Resistance; LDL-C: low-density lipoprotein cholesterol; MetS: metabolic syndrome; NA: not applicable; PA: physical activity; SBP: systolic blood pressure; WM: weight maintenance. ${ }^{\mathrm{a}}$ If a study had all-cause mortality and cause-specific morality as outcomes, we only reported the number of total deaths. For non-mortality outcomes, we reported number of cases for each disease outcome unless the outcome was continuous measurement (instead of disease status) for which we only reported all the participants in the study. ${ }^{b}$ Population at risk are normal disease-free individuals unless otherwise noted. ${ }^{c}$ Covariates were those adjusted in the final fully adjusted substitutional association model. ${ }^{\mathrm{d}}$ The substitutional effect estimates from three cohorts were computed by fixed-effects meta-analysis. ${ }^{\mathrm{e}}$ In this 6-month weight maintenance study following an energy-restricted diet for weight loss, dietary intake during the 26-week was calculated as the mean intake reported in the 3-day food diaries at week 4 and week 26. ${ }^{\mathrm{f}}$ The DAI was calculated as the total sum of points assigned to each deficit divided by the number of deficits considered (52 in total for 4 domains: functional impairments, self-reported health/vitality, mental health, and morbidities/use of health services) and further multiplied by 100 to obtain a range from 0 (lowest) to $100 \%$ (highest deficit accumulation). ${ }^{\mathrm{g}}$ The sarcopenia risk score was the composite z-scores calculated and averaged by the sex-specific standardized values of skeletal muscle mass index and handgrip strength. 


\subsection{Quality Assessment}

The methodological quality of included studies was also independently assessed by two authors with reference to the Newcastle-Ottawa Quality Assessment Scale (NOS) [40]. Stars were assigned to each study based on NOS criteria for study selection, comparability and outcome, with a maximum of 9 stars for cohort study and 10 stars for cross-sectional studies, and studies with 7 or more stars were considered to be of adequate quality [40]. The discrepancies in the study selection and quality assessment were resolved by consulting with a third reviewer (J.Z.).

\section{Results}

A total of 1822 records were identified from PubMed and Embase after removing duplicates, among which full-text review was conducted for 103 articles. After excluding studies not meeting the inclusion criteria with reasons listed in Figure 1, 12 articles published between 2005 and 2021 were included for final analyses [7,10,29-38]. Among these, 1 article described substitution results only based on the combined dataset of 2 prospective cohorts [10] and another reported substitutional effects based on fixed-effects meta-analysis of 3 prospective cohorts without individual study results [33], while all the others described only 1 population in the study; therefore, we reported associations from a total of 12 studies in the present review. In the assessment of the study quality, all 12 studies scored 7 and above according to NOS, so they were all retained in this review.

\subsection{Study Characteristics}

We included 9 prospective cohort studies [7,10,29-33,35,37] and 3 cross-sectional studies $[34,36,38]$ with a total of 1,450,178 participants aged from 15 to 79 years, in the review (Table 2). Two cross-sectional studies were conducted at baseline within respective European cohort studies [34,38], and another cross-sectional analysis was conducted within a clinical trial, i.e., European Diet, Obesity and Genes Trial (DIOGenes) [36]. Of the 9 cohort studies, 6 were conducted in the United States [10,30-33,35], 2 in Europe [7,37] and 1 in Japan [29], with mean or median follow-up time ranging from 7 years [37] to the longest 27 years [10]. A total of 156,064 overall deaths including 55,505 deaths from cancer and 41,836 deaths from CVD were identified from 5 cohort studies [10,29-31,35] while a total of 29,851 incident cases of various aging-related diseases were identified from the other 4 cohort studies [31-33,37], which consisted of 13,838 cancer cases, 15,580 T2D cases, 298 hypertension cases, and 135 microalbuminuria cases. Two studies in the review included female participants only [31,35], and one study reported sex-specific associations only [30], whereas all the other studies presented substitutional associations among men and women combined. Other than two studies conducted among diseased populations (i.e., type-1 diabetes [37] and T2D [38]), the other studies in this review were conducted in disease-free populations.

The food frequency questionnaire (FFQ) was the most common instrument used to assess diet intake $(n=8)[10,29-33,35,38]$ with 122 to 177 included food items and was selfadministered in all of the 8 studies. Food records were applied in 3 studies for participants to carefully document either a 3-day [36,37] or 1-week diet [34]. In the other study, a computerized diet history covering 900 items was used [7]. Diet was measured only once in the majority of studies; however, in two Harvard pooling cohort studies diet was measured repeatedly at baseline and every 4 years thereafter, and cumulative average dietary intake was analyzed $[10,33]$ and diet was measured at 2 time points in 2 studies to calculate the average [36] or change [7] of protein intake between the 2 measurements respectively. FFQ or the computerized diet history evaluated diet over the previous 1 year in the majority of studies $(n=7)$, over the past 3 months in one study [35], and in the past month in another study [38]. Both validity and reproducibility of diet questionnaires were assessed in seven studies [10,29-33,35], and only validity was assessed in two studies [7,38].

In regard to the substituted protein exposure in the isocaloric substitution model, nine used "percentage of energy" as the unit of the substituted exposure $[7,10,29-31,33,35,37,38]$ 
while the other three studies used percentage of total protein [36], quintiles of amount of protein intake [32], and grams of protein per body weight [34]. Among the 9 studies using "percentage of energy" as protein substitution unit, 5 reported the substitutional associations with the unit as 3\% of energy from animal-based or plant-based proteins for substitution $[10,29,30,37,38]$, 2 reported the protein substitutional effect based on each $5 \%$ of energy intake [33,35], 1 on each $1 \%$ of energy intake [7], and another one comparing the highest versus lowest quintile of the percentage of energy from plant proteins substituted for animal proteins [31]. In two studies [37,38], both isocaloric substitutional effects of plant protein for animal protein and animal protein for plant protein were reported, while other studies only reported the effect of plant protein intake substituted for animal protein intake. While seven studies only reported the substitutional effect of total plant and total animal protein [31,33-38], the other five studies included investigation on protein from specific food sources $[7,10,29,30,32]$. In a majority of substitution models, the isocaloric substitution of plant and animal protein was calculated by including all macronutrients except the replaced exposure $(n=5)$ or by controlling for total protein intake $(n=3)$, but carbohydrate was accounted for by including vegetables, fruits, glycemic index or fiber instead of controlling for carbohydrate directly in the other studies [10,30,33,35]. The aging-related health outcomes reported in this review included all-cause and cause-specific mortality outcomes [10,29-31,35], T2D [33], total cancer and colorectal cancer [31,32], hypertension [37], renal function impairment and microalbuminuria [37,38], cardiometabolic risk markers [36] and two aging-related indices, i.e., sarcopenia risk score (SRS) [34] and deficit accumulation index (DAI) [7]. In the multivariable models, most studies adjusted for important confounders associated with dietary protein intake and disease, including age, sex, body mass index, physical activity, alcohol consumption, cigarette smoking, personal medical history, total energy intake and other macronutrients $(n=8)$; of these, three additionally adjusted for family history of the relevant disease $[31,32,35]$ and four additionally adjusted for socioeconomic status [7,30,32,35].

\subsection{Substitution of Protein from Animal and Plant Sources and Mortality Outcomes}

Five cohort studies (four in the United States [10,30,31,35] and one in Japan [29]) reported the associations of various plant-based proteins substituted for different types of animal-based proteins with mortality outcomes including all-cause mortality, CVD-specific mortality, total cancer mortality, and respiratory disease mortality (Figure S1) [10,29-31,35].

Except for the Iowa Women's Health Study (IWHS) in which quintiles of total plant protein intake were analyzed as the substituted exposure [35], all 5 studies on all-cause mortality consistently supported a significant lower all-cause mortality risk when substituting $3 \%$ or $5 \%$ energy intake from total plant protein for total animal protein $[30,35]$ and specific animal proteins including red and/or processed meat $[10,29,30]$, white meat [30], poultry [10], fish [10,29], and eggs [10,29,30] with RRs ranging from 0.54 to 0.95 (Figure S1A). Among these, the strongest risk reduction was observed for substituting 3\% energy from total plant protein for processed meat protein $(\mathrm{HR}=0.54,95 \% \mathrm{CI}=0.38-0.75)$, which was identified in the Japan Public Health Center-based (JPHC) cohort [29] with 12,381 total deaths after a mean of 18 years of follow-up, followed by substitution for red meat protein ( $\mathrm{HR}=0.66,95 \% \mathrm{CI}=0.55-0.80)$ in the same JPHC cohort and for processed red meat $(\mathrm{HR}=0.66,95 \% \mathrm{CI}=0.59-0.75)$ based on the finding from the pooling cohort of the Nurses' Health Study (NHS) and the Health Professionals Follow-up Study (HPFS) [10]. However, inverse association between substitution of plant protein for dairy protein with all-cause mortality was only seen in two U.S. cohorts $[10,30]$ but not in the Japanese cohort [29]. In the U.S. National Institutes of Health-American Association of Retired Persons (NIH-AARP) study by Huang et al., substituting specific plant proteins in addition to total plant protein for red meat protein and egg protein in relation to all-cause mortality was also examined [30]. For both males and females, among different plant proteins, the significant reduced all-cause mortality was limited to bread, cereal and pasta protein when 
replacing red meat protein. Changing from egg protein to all-plant proteins except nut protein significantly reduced all-cause mortality [30].

In terms of total cancer mortality, four prospective cohort studies reported its association with isocaloric substitution of plant protein for animal protein (Figure S1B) [10,29-31]. All the studies used 3\% energy intake from plant protein substituted for animal protein as the exposure except in the IWHS study, in which substitution of highest vs lowest quintile of percentage of energy from plant protein for animal protein was analyzed [31]. A significant lower cancer mortality risk was demonstrated for increased intake of total plant protein to the detriment of total animal protein among females but not males in the NIH-AARP cohort [30], while there was an association in the IWHS cohort where a different type of substitution exposure was applied [31]. When examining substitutional effects for specific sources of animal protein, a change from red meat protein to plant protein was significantly associated with a $7 \%$ to $39 \%$ reduced cancer mortality risk in the JPHC and NIH-AARP cohorts [29,30], but in the pooled NHS and HPFS, neither processed red meat protein nor unprocessed red meat protein was associated with cancer mortality when replaced with plant protein [10]. In general, substituting plant protein for overall white meat protein or specific white meat proteins (i.e., poultry and fish protein) as well as dairy protein was not associated with cancer mortality, and the substitutional effect of plant protein for egg protein was not consistent $[10,29,30]$. Moreover, in the analysis of specific plant protein sources in the NIH-AARP study, substitution of 3\% energy from plant protein from bread, cereal and pasta for either red meat protein or egg protein significantly lowered cancer mortality risk by $12 \%$ in men and $13 \%$ in women, and by $18 \%$ in men and $20 \%$ in women, respectively [30]. Beans and legumes protein significantly reduced cancer mortality among women only when substituted for red meat or egg protein. Other plant proteins were not associated with cancer mortality risk among both sexes when replacing red meat or egg protein [30].

Four cohort studies (three studies in the United States [10,30,35] and one in Japan [29]) reported associations between CVD-specific mortality and substitution of plant proteins for animal proteins (Figure S1C). Significantly lower CVD mortality risk was associated with substitution of total plant protein for total animal protein in both sexes, with HRs ranging from 0.78 to $0.89[30,35]$, and the significant lower risk was also confirmed when total plant protein replaced various specific animal proteins, including total red meat, processed red meat and unprocessed red meat, white meat, and poultry with HRs varying from 0.58 to $0.91[10,29,30]$. When examining specific sources of plant protein in replacing $3 \%$ energy from egg protein and red meat protein, reduced risk of CVD mortality was only observed with substitution of bread, cereal and pasta protein for red meat protein (HRs for both sexes $=0.76)$ and egg protein ( $\mathrm{HR}=0.67$ for males and $\mathrm{HR}=0.69$ for females $)$ in the NIH-AARP study, plant protein from other sources (such as soy protein) was also related to reduced CVD mortality when replacing the same amount of egg or red meat protein but was only found among females [30]. When it comes to mortality from specific CVD diseases, the mortality risk of coronary heart disease was significantly reduced by $30 \%(\mathrm{HR}=0.70,95 \%$ $\mathrm{CI}=0.51-0.98$ ) when comparing an average substitution of $6.1 \%$ versus $3.7 \%$ energy from total plant protein for total animal protein in the Iowa menopausal women cohort (Figure S1D) [31]. The associations with heart disease-specific and stroke-specific mortality were only investigated in the NIH-AARP study where replacement of total animal protein with total plant protein significantly reduced mortality from heart disease by $10 \%$ in both sexes and the protective effect was consistently presented when exchanging plant protein for different animal proteins including red meat protein, dairy protein, and egg protein with HRs ranging from 0.72 for egg protein to 0.92 for dairy protein (Figure S1D,E) [30]. When examining different food sources of plant protein, investigators only observed significant lower heart disease mortality when bread, cereal and pasta protein replaced red meat protein $(\mathrm{HR}=0.77$ for males and $\mathrm{HR}=0.78$ for females) or egg protein ( $\mathrm{HR}=0.68$ for males and HR $=0.69$ for females) in this American retired population. Similarly, as for stroke mortality, substitution of total plant protein for a variety of animal proteins from 
overall animal protein, red meat protein and dairy protein was all found to be significantly associated with a reduced mortality risk among both sexes, with HRs from 0.75 to 0.81 (Figure S1E). The significant effect was also limited to the plant protein from bread, cereal, and pasta when replacing red meat or egg protein [30].

Findings from the NIH-AARP study revealed that significantly reduced respiratory disease mortality was only observed with substitution of 3\% energy from total plant protein for red meat protein ( $\mathrm{HR}=0.83$ for males and $\mathrm{HR}=0.80$ for females) and egg protein ( $\mathrm{HR}=0.61$ for males and $\mathrm{HR}=0.66$ for females) (Figure S1F) [30]. Bread, cereal, and pasta protein was the only source of plant protein that was associated with lower respiratory disease mortality when replacing red meat protein. Both bread, cereal, and pasta protein and protein from other plant sources reduced respiratory disease mortality when replacing egg protein. However, a significantly increased risk was reported in exchanging plant protein for white meat protein, but this only occurred in males $(\mathrm{HR}=1.17,95 \% \mathrm{CI}=1.03-1.33)$ [30]. As for dementia mortality, a significant lower mortality risk was reported in the WHI study where $5 \%$ energy of animal protein was replaced with total plant protein $(\mathrm{HR}=0.81,95 \%$ $\mathrm{CI}=0.68-0.97)[35]$.

\subsection{Substitution of Plant Protein for Animal Protein and Risk of Aging-Related Diseases}

A total of six studies reported isocaloric substitutional effects of plant and animal protein intake on incidence or prevalence risk of different aging-related diseases: two studies focused on total cancer [31] or colorectal cancer (CRC) risk [32], one study analyzed data of three cohorts reported T2D risk [33], one on hypertension risk [37], and two studies investigated chronic kidney disease and microalbuminuria risk (Figure 2) [37,38]. No association for substitution of total plant for total animal protein on overall cancer risk was observed in the IWHS ( $R R=0.99,95 \% \mathrm{CI}=0.87-1.13)$ [31]. In contrast, the NIH-AARP study reported an inverse association with overall $\mathrm{CRC}$ risk $\left(\mathrm{HR}_{\mathrm{Q} 5 \mathrm{VS} . \mathrm{Q} 1}=0.91,95 \% \mathrm{CI}\right.$ $\left.=0.83-0.99 ; P_{\text {trend }}=0.04\right)$, rectal cancer risk $\left(\mathrm{HR}_{\mathrm{Q} 5 \mathrm{VS} . \mathrm{Q} 1}=0.84,95 \% \mathrm{CI}=0.71-1.00\right)$, and distal colon cancer risk $\left(\mathrm{HR}_{\mathrm{Q} 5} \mathrm{VS} . \mathrm{Q} 1=0.84,95 \% \mathrm{CI}=0.71-0.99\right)$ but not with proximal colon cancer risk. The inverse associations appeared to be limited to substituting total plant protein for red meat protein [32]. When further evaluating different plant proteins, the significant reduction in CRC risk was only limited to the substitution of protein from bread, cereal, and pasta for red meat protein, and this protective effect was stronger for rectal cancer and distal colon cancer than proximal colon cancer [32].

In the fixed-effect meta-analysis of the NHS, NHS II and HPFS cohorts where 205,802 participants were followed up for an average of 20 years with 15,580 incident T2D cases documented, T2D was significantly reduced by $23 \%(95 \% \mathrm{CI}=0.70-0.84)$ when substituting $5 \%$ of energy intake from total plant protein for total animal protein; consistently, a $2 \%$ to $21 \%$ reduced T2D risk was observed when substituting 1 serving per day of plant protein foods for an equal exchange of animal protein foods [33].

In the EURODIAB Prospective Complications Study with the aim to investigate baseline dietary protein intake in relation to risk of hypertension and microalbuminuria as an early clinical sign of nephropathy in 2364 type-1 diabetics from 16 European countries, no associations of hypertension and microalbuminuria risk were found with either replacement of $3 \%$ of energy from plant protein with animal protein or replacement of $3 \%$ of energy from animal protein with plant protein [37]. In the cross-sectional analyses conducted at baseline of the Dutch DIAbetes and LifEstyle Cohort Twente-1 (DIALECT-1) cohort among 420 patients with T2D, substitution of 3\% energy intake from total plant protein for total animal protein significantly reduced prevalence of renal function impairment also known as chronic kidney disease (prevalence ratio $=0.20,95 \% \mathrm{CI}=0.07-0.63$ ) [41], but in a reverse way, replacing 3\% energy from plant protein with animal protein was associated with a $31 \%$ non-significant increased prevalence risk of chronic kidney disease [38]. 


\begin{tabular}{|c|c|c|c|c|c|c|}
\hline Incidence or prevalence risk ${ }^{*}$ & Protein substitution $^{\dagger}$ & Study ${ }^{*}$ & & & RR (95\%Cl) & $P_{\text {trend }}{ }^{* *}$ \\
\hline Total cancer & Plant $\rightarrow$ Animal (Q5 vs Q1) & Kelemen 2004 (women) & $\mapsto$ & + & $0.99(0.87,1.13)$ & 0.92 \\
\hline \multirow[t]{8}{*}{ Colorectal cancer } & Plant $\rightarrow$ Animal (Q5 vs Q1) & Liao 2019 & $\mapsto$ & & $0.91(0.83,0.99)$ & 0.04 \\
\hline & Plant $\rightarrow$ Red meat (Q5 vs Q1) & Liao 2019 & $\mapsto$ & & $0.89(0.81,0.97)$ & 0.01 \\
\hline & Plant $\rightarrow$ White meat (Q5 vs Q1) & Liao 2019 & $\mapsto$ & & $0.96(0.88,1.05)$ & 0.44 \\
\hline & Plant $\rightarrow$ Other animal sources (Q5 vs Q1) & Liao 2019 & $\mapsto$ & & $0.94(0.86,1.03)$ & 0.22 \\
\hline & Bread, cereal, and pasta $\rightarrow$ Red meat (Q5 vs Q1) & Liao 2019 & $\mapsto-1$ & & $0.86(0.80,0.93)$ & $<0.0001$ \\
\hline & Nuts $\rightarrow$ Red meat (Q5 vs Q1) & Liao 2019 & the & & $0.95(0.89,1.02)$ & 0.26 \\
\hline & Beans and legumes $\rightarrow$ Red meat (Q5 vs Q1) & Liao 2019 & & $\rightarrow-1$ & $1.02(0.94,1.10)$ & 0.69 \\
\hline & Other plant sources $\rightarrow$ Red meat (Q5 vs Q1) & Liao 2019 & & - & $1.01(0.92,1.11)$ & 0.94 \\
\hline \multirow[t]{8}{*}{ Colon cancer } & Plant $\rightarrow$ Animal (Q5 vs Q1) & Liao 2019 & $\mapsto$ & & $0.94(0.85,1.04)$ & 0.2 \\
\hline & Plant $\rightarrow$ Red meat (Q5 vs Q1) & Liao 2019 & $\mapsto$ & & $0.90(0.81,1.00)$ & 0.05 \\
\hline & Plant $\rightarrow$ White meat (Q5 vs Q1) & Liao 2019 & & - & $0.97(0.87,1.08)$ & 0.61 \\
\hline & Plant $\rightarrow$ Other animal sources (Q5 vs Q1) & Liao 2019 & $\mapsto$ & & $0.97(0.87,1.07)$ & 0.54 \\
\hline & Bread, cereal, and pasta $\rightarrow$ Red meat (Q5 vs Q1) & Liao 2019 & $\mapsto$ & & $0.89(0.82,0.97)$ & 0.003 \\
\hline & Nuts $\rightarrow$ Red meat (Q5 vs Q1) & Liao 2019 & to & & $0.94(0.87,1.02)$ & 0.33 \\
\hline & Beans and legumes $\rightarrow$ Red meat (Q5 vs Q1) & Liao 2019 & & $\rightarrow$ & $0.99(0.91,1.08)$ & 0.94 \\
\hline & Other plant sources $\rightarrow$ Red meat (Q5 vs Q1) & Liao 2019 & & 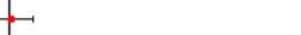 & $1.01(0.91,1.13)$ & 0.96 \\
\hline \multirow[t]{8}{*}{ Proximal colon cancer } & Plant $\rightarrow$ Animal (Q5 vs Q1) & Liao 2019 & & 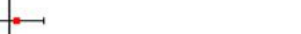 & $1.04(0.91,1.19)$ & 0.48 \\
\hline & Plant $\rightarrow$ Red meat (Q5 vs Q1) & Liao 2019 & & $\longrightarrow$ & $1.02(0.89,1.17)$ & 0.71 \\
\hline & Plant $\rightarrow$ White meat (Q5 vs Q1) & Liao 2019 & & 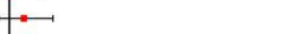 & $1.08(0.94,1.24)$ & 0.22 \\
\hline & Plant $\rightarrow$ Other animal sources (Q5 vs Q1) & Liao 2019 & & 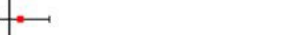 & $1.06(0.93,1.22)$ & 0.3 \\
\hline & Bread, cereal, and pasta $\rightarrow$ Red meat (Q5 vs Q1) & Liao 2019 & $\vdash$ & $\rightarrow$ & $0.99(0.88,1.11)$ & 0.62 \\
\hline & Nuts $\rightarrow$ Red meat (Q5 vs Q1) & Liao 2019 & $\mapsto$ & & $0.93(0.84,1.03)$ & 0.53 \\
\hline & Beans and legumes $\rightarrow$ Red meat (Q5 vs Q1) & Liao 2019 & & $\longrightarrow$ & $1.02(0.91,1.14)$ & 0.44 \\
\hline & Other plant sources $\rightarrow$ Red meat (Q5 vs Q1) & Liao 2019 & & $\longrightarrow$ & $1.06(0.92,1.22)$ & 0.61 \\
\hline \multirow[t]{8}{*}{ Distal colon cancer } & Plant $\rightarrow$ Animal (Q5 vs Q1) & Liao 2019 & $\longmapsto$ & & $0.84(0.71,0.99)$ & 0.02 \\
\hline & Plant $\rightarrow$ Red meat (Q5 vs Q1) & Liao 2019 & $\longmapsto$ & & $0.79(0.67,0.94)$ & 0.003 \\
\hline & Plant $\rightarrow$ White meat (Q5 vs Q1) & Liao 2019 & $\longmapsto$ & & $0.86(0.72,1.01)$ & 0.04 \\
\hline & Plant $\rightarrow$ Other animal sources (Q5 vs Q1) & Liao 2019 & $\longmapsto$ & & $0.87(0.74,1.03)$ & 0.06 \\
\hline & Bread, cereal, and pasta $\rightarrow$ Red meat (Q5 vs Q1) & Liao 2019 & $\mapsto$ & & $0.78(0.67,0.90)$ & 0.0001 \\
\hline & Nuts $\rightarrow$ Red meat (Q5 vs Q1) & Liao 2019 & $\mapsto$ & & $0.90(0.79,1.03)$ & 0.16 \\
\hline & Beans and legumes $\rightarrow$ Red meat (Q5 vs Q1) & Liao 2019 & $\longmapsto$ & - & $0.97(0.84,1.12)$ & 0.52 \\
\hline & Other plant sources $\rightarrow$ Red meat (Q5 vs Q1) & Liao 2019 & $\longmapsto$ & 七 & $0.94(0.79,1.12)$ & 0.49 \\
\hline \multirow[t]{8}{*}{ Rectal Cancer } & Plant $\rightarrow$ Animal (Q5 vs Q1) & Liao 2019 & $\longmapsto$ & & $0.84(0.71,1.00)$ & 0.06 \\
\hline & Plant $\rightarrow$ Red meat (Q5 vs Q1) & Liao 2019 & $\mapsto$ & & $0.84(0.71,1.00)$ & 0.07 \\
\hline & Plant $\rightarrow$ White meat (Q5 vs Q1) & Liao 2019 & $\longmapsto$ & 一 & $0.93(0.78,1.12)$ & 0.5 \\
\hline & Plant $\rightarrow$ Other animal sources (Q5 vs Q1) & Liao 2019 & $\longmapsto$ & 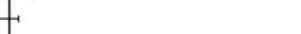 & $0.88(0.74,1.05)$ & 0.18 \\
\hline & Bread, cereal, and pasta $\rightarrow$ Red meat (Q5 vs Q1) & Liao 2019 & $\mapsto$ & & $0.78(0.67,0.91)$ & 0.0004 \\
\hline & Nuts $\rightarrow$ Red meat (Q5 vs Q1) & Liao 2019 & $\mapsto$ & - & $0.98(0.86,1.12)$ & 0.59 \\
\hline & Beans and legumes $\rightarrow$ Red meat (Q5 vs Q1) & Liao 2019 & & 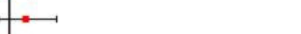 & $1.09(0.94,1.26)$ & 0.37 \\
\hline & Other plant sources $\rightarrow$ Red meat (Q5 vs Q1) & Liao 2019 & $\longmapsto$ & 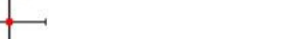 & $1.00(0.83,1.20)$ & 0.99 \\
\hline Type 2 diabetes & Plant $\rightarrow$ Animal $(5 \%)$ & Malik 2016 & $\leftrightarrow$ & & $0.77(0.70,0.84)$ & - \\
\hline \multirow[t]{2}{*}{ Hypertension } & Plant $\rightarrow$ Animal $(3 \%)$ & der Kuil 2013 & & 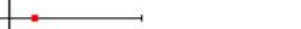 & $1.14(0.75,1.73)$ & - \\
\hline & Animal $\rightarrow$ Plant $(3 \%)$ & der Kuil 2013 & $\rightarrow$ & $\longrightarrow$ & $0.79(0.52,1.21)$ & - \\
\hline \multirow[t]{2}{*}{ Microalbuminuria } & Plant $\rightarrow$ Animal $(3 \%)$ & der Kuil 2013 & & & $0.94(0.53,1.67)$ & - \\
\hline & Animal $\rightarrow$ Plant $(3 \%)$ & der Kuil 2013 & & $\rightarrow$ & $1.20(0.66,2.19)$ & - \\
\hline \multirow[t]{3}{*}{ Renal function impairment } & Plant $\rightarrow$ Animal $(3 \%)$ & Oosterwijk 2019 & & & $0.20(0.06,0.63)$ & - \\
\hline & Animal $\rightarrow$ Plant $(3 \%)$ & Oosterwijk 2019 & & $\rightarrow$ & $1.31(0.94,1.83)$ & - \\
\hline & & & 1 & 25 & & \\
\hline
\end{tabular}

Figure 2. Forest plot of incidence or prevalence risk of aging-related diseases in relation to isocaloric substitution of plant-based protein and animal-based protein. * In the study by Oosterwijk et al., the outcome was prevalence risk of renal function impairment while the outcome was incidence risk in the rest of the studies. "Symbol " $\rightarrow$ " represents substitution of protein from the left-side food source for protein from the right-side food source. "Plant" and "Animal" stands for "all the plant-based food sources" and "all the animal-based food sources", respectively. The content in the bracket after the substitution exposure describes the substituted exposure's unit and data type: "Q5 vs. Q1" in the study by Kelemen et al. was substitution of Quintile 5 versus Quintile 1 of percentage of energy from total plant protein for total animal protein. In the study by Liao et al., the exposure was the substitution of Quintile 5 versus Quintile 1 of amount of plant-based protein for animal-based protein. " $3 \%$ " or " $5 \%$ " in the rest of studies referred to substitution of $3 \%$ or $5 \%$ of total energy intake from various plant-based proteins for various animal-based proteins. $¥$ The content in the bracket after reference of publication indicated the population in the analysis, both sexes combined if not otherwise indicated. ${ }^{* *}$ The $P_{\text {trend }}$ value was only reported for the categorical substituted exposure. 


\subsection{Substitution of Plant Protein for Animal Protein and Cardiometabolic Risk Markers}

A cross-sectional analysis within the European DIOGenes trial was conducted in 489 overweight and obese participants. Average dietary intake was assessed with two 3-day food records for each participant in a 26-week weight maintenance intervention period when changes in body weight, body fat, and cardiometabolic risk markers were also measured [36]. No association was found for change of any cardiometabolic risk markers including body composition, serum lipids, insulin homeostasis and inflammatory biomarkers, systolic and diastolic blood pressure with increasing $1 \%$ of animal protein at the cost of plant protein.

\subsection{Substitution of Plant Protein for Animal Protein and Indices Associated with Unhealthy Aging}

Two studies reported significant inverse associations between the substitution of plant protein for animal protein and a priori indices associated with unhealthy aging among older adults [7,34]. In the Seniors-Study on Nutrition and Cardiovascular Risk in Spain (Seniors-ENRICA) cohort, change of DAI from baseline at 2008-2010 (wave 0) to 2017 (wave 3) was measured among 812 participants with a mean age of 68.6 years old, with higher DAI indicating higher degree of deficit accumulation that covered 4 domains of unhealthy aging, including functional impairments, self-reported vitality, mental health, and morbidities. DAI was significantly reduced by $0.46 \%, 0.52 \%$ and $0.47 \%$ with each $1 \%$ energy intake increase from baseline to wave 1 (2012) in the substitution of total plant protein for total animal protein, dairy protein, and meat protein, respectively [7]. At baseline of the European Project on Nutrition in Elderly People (NU-AGE) cohort of European adults aged 65-79, the SRS was measured to represent muscle quantity and strength with a higher score indicating lower muscle health. SRS was significantly reduced with each $0.1 \mathrm{~g} / \mathrm{body}$ weight increase of plant protein intake to the detriment of animal protein while keeping total protein intake constant, across different levels of total protein intake (Figure 3) [34].

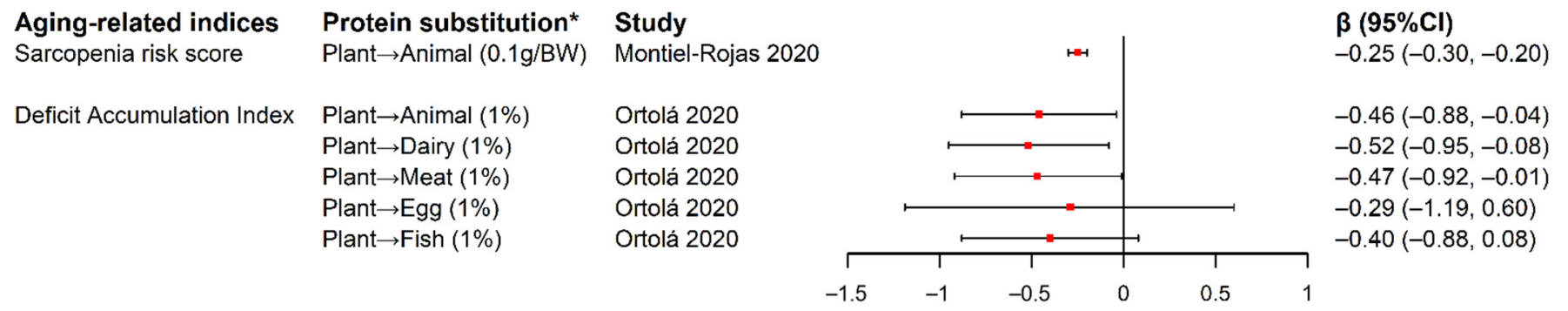

Figure 3. Forest plot of estimated changes and 95\% CIs in aging-related indices in relation to isocaloric substitution of plant-based protein for animal-based protein. ${ }^{*}$ Symbol " $\rightarrow$ " represents substitution of protein from the left-side food source for protein from the right-side food source. "Plant" and "Animal" stands for "all the plant-based food sources" and "all the animal-based food sources", respectively. The content in the bracket after the substitution exposure describes the substituted exposure's unit and data type: "0.1g/BW" in the study by Montiel-Rojas et al. was substitution of $0.1 \mathrm{~g}$ total plant protein per body weight for the detriment of total animal protein. " $1 \%$ " in the study by Ortolá et al. referred to substitution of $1 \%$ of total energy intake from total plant protein for various animal-based proteins. Abbreviation: BW, body weight; $\mathrm{CI}$, confidence interval.

\section{Discussion}

Published evidence identified in this systematic review supported a significantly reduced risk of all-cause and CVD-specific mortality in relation to isocaloric substitution of total plant protein for animal proteins from various sources. The strongest protective effect was mainly observed when substituting plant protein for red and/or processed meat protein. Further examination of specific plant proteins revealed the reduced mortality risk was limited to bread, cereal, and pasta protein when replacing red meat protein. Too few studies were identified on other aging-related health outcomes such as cancer incidence, 
T2D, and indices associated with unhealthy aging to draw firm conclusions, though there was suggested reduced risk of incident CRC and T2D, as well as decreased unhealthy aging scores in association with isoenergetic substitution of plant protein for animal protein.

Our finding of the protective role of isocaloric substitution of plant protein for animal protein against several aging-related health outcomes had inherent consistency in many ways. Significant reduced risk of all-cause mortality, CVD mortality as well as subtypes of CVD mortality (i.e., stroke- and heart-disease-specific mortality) was consistently observed with total plant protein replaced by multiple animal proteins, including red and/or processed meat, egg, and dairy protein $[10,29,30,35]$, which indicated exchanging plant protein for animal protein regardless of animal food sources can be protective against mortality risk, particularly CVD disease mortality. We also observed a significant protective substitutional effect of plant protein for red meat protein on all-cause mortality and CVD mortality, with the effect consistent for processed and unprocessed red meat $[10,29,30]$, suggesting the protein substitutional effect was independent of meat processing. Consistency in substitutional associations was also reflected by the observations that the protective effect of substituting plant proteins for animal proteins existed not only for a broader or overall disease category but also for their subtypes (i.e., reduced mortality risk of CVD and CVD subtypes such as heart disease and stroke [10,29,30,35], overall CRC risk and by subsite [32]). Two aging-related indices (i.e., SRS and DAI) reflected the aging-related health status from different aspects with a higher score indicating a higher degree of unhealthy aging, and they were both significantly reduced when replacing total animal protein with total plant protein [7,34]. Huang et al. conducted sex-specific substitutional associations in the NIH-AARP study that generated similar findings across both sexes for multiple mortality outcomes, except that females tended to have a stronger protective effect from substituting other plant protein such as soy protein for red meat protein against all-cause and CVD mortality than males, which could be the differential gender effect of soy and isoflavones intake on CVD mortality that was supported in previous cohort studies $[30,42,43]$. In a large Japanese cohort of 40,462 participants aged between 40 to 59 years old, an inverse association between isoflavone intake and risk of myocardial infarctions and ischemic CVD mortality was observed among women only [42]. Similarly, in a cross-sectional study among 2811 Chinese men and women, habitual soy protein intake had sex-dependent effects on the risk of metabolic syndrome, a clinical risk factor for CVD; while women had lower risk associated with higher soy protein intake, men had higher risk [43]. In an intervention study of 41 hypercholesterolemic men and postmenopausal women who underwent high- and low-isoflavone soy food test phases, significantly higher interleukin-6 values after the high-isoflavone soy diet only appeared in women, indicating an estrogenic effect of soy isoflavones in enhancing the immune response among women, and thus the enhanced immune surveillance could lower risk of proinflammatory diseases such as CVD and cancer [44]. Although estrogen exerts a cardioprotective effect, there are still conflicting data regarding the beneficial or adverse effects of phytoestrogens on cardiovascular health, as phytoestrogens may act as both estrogen agonists and antagonists [45].

We observed an unexpected significant positive association between substitution of plant protein for white meat protein and respiratory disease mortality among men only in the NIH-AARP study [30], different from the substitutional associations observed with other mortality outcomes in this population. Although it was not clear which food source or component contributed primarily to white meat and plant protein in this substitutional association, the unexpected opposite direction suggested a stronger inverse association of white meat protein than plant protein with mortality from respiratory disease, or a stronger positive association of plant protein compared to white meat protein with respiratory disease mortality among males in this cohort, or this could just be a chance finding. We also noticed the different associations with total cancer mortality and all-cause mortality when using categorical (Quintile 5 vs. Quintile 1) versus continuous exposure ( $3 \%$ energy) of total plant protein substituted for total animal protein as the exposure, with the former reaching no association but an inverse association from the latter exposure [30,31]. This review 
included two studies that investigated both substitution of plant protein for animal protein and animal protein for plant protein as exposures with same outcome $[37,38]$; interestingly, the two-way substitution did not generate reciprocal estimates. This could be due to the two different exposure variables in the same adjusted model that often produce uncorrelated estimates statistically, and may also be due to the different strengths and significance of independent effects of animal and plant proteins on the outcome. This suggested the substitutional effect on disease outcome was not only dependent on the substitute and the one being replaced, but also dependent on the direction of the substitution.

This review only included studies applying the "leave-one-out" nutritional substitution model, with interpretation focusing on the substitutional effect of the protein in the model for the protein left out of the model with other macronutrients and total energy intake controlled as a constant. The interpretation from this model is different from the other "independent effect" nutritional model with no macronutrient left out that expresses the independent effect of a macronutrient of interest on a given outcome with adjustment for all other macronutrients. In general, independent effects of animal and vegetable proteins on all-cause and CVD mortality risk and CRC and T2D incidence risk summarized from previous literature support the plant and animal protein substitutional effects we summarized in this review. A recent large meta-analysis of 31 prospective cohort studies searched until December 2019 with 16,429 CVD deaths and 22,303 cancer deaths occurred among 715,128 participants reported that intake of total plant protein was significantly associated with a lower risk of all-cause mortality (pooled $R R=0.92$ ) and CVD mortality (pooled $R R=0.88$ ), but not with cancer mortality [25]. Particularly, per $90 \mathrm{~g} /$ day increase in whole grain intake was found to be significantly associated with $12 \%$ to $22 \%$ reduced mortality risk for CVD diseases including coronary heart disease and stroke, and intakes of specific types of whole grains including whole grain bread, total bread, and breakfast cereals were also associated with reduced risks of CVD and all-cause mortality [46]. On the contrary, there was a small positive association between unprocessed red meat intake and processed meat intake with all-cause and CVD mortality in a meta-analysis of 17 prospective cohorts [47]. In the NIH-AARP study, substitution of plant protein, particularly protein from bread, cereal, and pasta, for egg protein was associated with a strong decreased risk of stroke and heart disease mortality; however, previous literature did not consistently suggest a positive link between egg consumption and overall cardiovascular disease events or stroke, and therefore, the observed significant inverse association with substitution for egg protein possibly comes from plant protein, especially cereal protein's cardiovascular protective effect $[48,49]$. A systematic search in several databases for prospective studies investigating the associations between 12 major food groups and the risk of CRC and T2D came to the conclusion of a significant inverse association with whole grains and a positive association with red meat and processed meat in a dose-response manner [50,51], which was in line with our observation of the significant reduced CRC risk and T2D risk when exchanging plant protein for animal protein in the few studies that have been done to date. Two recent meta-analyses of randomized controlled trials summarized the substitutional effect of plant protein for animal protein on glycemic control and blood lipids in an interventional setting $[52,53]$. Results from 13 trials focusing on replacing animal with plant protein at a median level of $\sim 35 \%$ of total protein per day on glycemic control in diabetes showed such a substitution led to a significantly lowered $\mathrm{HbA1c}$, fasting glucose and fasting insulin [53]. The other review with 112 trials on plant protein in substitution for animal protein of $\geq 3$ weeks found significantly decreased low-density lipoprotein cholesterol, non-high-density lipoprotein cholesterol and apolipoprotein B [52].

The underlying mechanisms for the observed protective effects of substitution of plant protein for animal protein on all-cause and CVD mortality risk as well as CRC and T2D risk may be attributable to differences between their food sources' co-occurring bioactive nutrients or compounds, amino acid composition, and certain microbiome-generated circulating metabolites $[30,51,54-56]$. Biochemical interactions between various nutrients or compounds in the protein food source can exert health effects, such that the effects of 
protein intake on disease may be due to other components of the food, not necessarily the protein content. Higher red and/or processed meat consumption has been consistently linked with multiple CVD risk factors such as abnormal serum lipid level, hypertension, and insulin resistance, possibly due to the nutrient profile associated with meat intake such as dietary cholesterol, heme iron, nitrates and nitrite, and advanced glycation end-products, some of which are carcinogenic compounds also related to increased risk of CRC and premature death $[12,15,54,56-58]$. High contents of phenolic compounds, vitamins, minerals, fiber, and phytoestrogens in grains and cereal foods has been associated with reduced cancer and CVD risk, mainly owing to their anti-inflammatory and antioxidant effect to improve metabolic profiles $[54,59,60]$. In terms of amino acid composition, plant-based protein is lower in essential amino acids (e.g., methionine, lysine, and tryptophan) but contains higher nonessential amino acids (e.g., arginine and glycine) that could favorably influence cardiovascular health by decreasing blood pressure and vascular reactive oxygen species $[54,61,62]$. In addition, fermentation by gut bacteria of undigested protein mainly contributed by animal protein into by-products such as ammonia, phenolic and indolic compounds, and hydrogen sulfide, was reported to promote alterations in colonic epithelial cells, leading to development of CRC [63]. Similarly, through gut microbiome metabolism, L-carnitine and choline from red meat intake formed the circulating trimethylamine-N-oxide (TMAO), a metabolite that increases major adverse cardiac events and CVD mortality [64]. However, limited evidence supports the benefits of plant- over animal-based protein on maintaining muscle mass [65]. In line with our finding of substituting plant protein for animal protein being associated with reduced dementia mortality and DAI, accumulating epidemiological evidence suggests a protective role in adherence to the Mediterranean diet emphasizing more plant-based food intake in neurodegenerative diseases and brain health, which could result from plant polyphenols' role in activating similar molecular pathways as caloric restriction diets [66].

Although there was not a large amount of evidence accumulated, current evidence on reduced risk of all-cause and CVD mortality in association with substitution of plant protein for animal protein was consistent across various food sources of animal proteins and across different diseases, and was also supported by recent reviews of the independent effects of specific protein intake and studies of biologic mechanisms. Moreover, given that the ideal isocaloric substitution of protein from different sources in an individual's daily life was hard to achieve, the current review provided accurate scientific evidence in this aspect by deriving the isoenergetic substitutional effects of animal and plant protein based on statistical modeling. However, several limitations to the previous literature should be noted. First of all, although several included studies described an isocaloric substitution model in the analyses, they did not adjust for carbohydrate but instead adjusted for vegetables, fruits, fiber, or glycemic index in the fully adjusted model, which could potentially lead to biased results and incomparability with other studies. Secondly, even among studies with the same outcome and same protein source for substitution, different exposure data type (i.e., continuous or quintiles) or units (3\% or $5 \%$ of energy) caused incomparability of study findings. Other differential aspects of included studies in this review included different study designs, different study population characteristics and disease statuses (diseased vs normal population), and results reported among different sexes (female only, male only, or both sexes combined). Thirdly, all the 9 studies using "percentage of energy" as protein substitution unit applied 1-5\% of energy as exposure, but this number was arbitrarily set; since a normal person usually consume $15 \%$ to $35 \%$ of energy from protein per day, future studies may consider using a higher cut-off for analysis to be more applicable to real-life situations. The majority of previous studies were conducted among primarily European descent, limiting the generalizability of the findings. Moreover, multiple biases might have occurred in the original studies. Several important confounders such as socioeconomic status, physical activity, and medical history were not controlled in some of the included studies. One-time diet assessment in most studies might lead to measurement bias, given diet may change over time. Use of self-reported FFQs, food 
record or other questionnaires collecting information might have led to information bias and thus caused non-differential misclassification. Residual or unmeasured confounding cannot be completely ruled out in observational studies. Our review is also limited by the scope of isocaloric substitution of two protein types; exchanging protein for fat or carbohydrate under isoenergetic condition was not investigated, though they are also common dietary substitution situations. Finally, there were a limited number of studies on each particular disease outcome, especially on cancers and metabolic diseases. In addition, no studies have focused on joint conditions including arthritis or other rheumatic disorders, one of the most prevailing aging-related outcomes in most Western countries. Future studies on these disease outcomes are warranted to provide a more conclusive summarization.

\section{Conclusions}

In summary, findings from this review suggested isocaloric substitution of plant-based protein for animal-based protein was inversely associated with risk of all-cause and CVD mortality, with the protective effect primarily contributed by substituting bread, cereal, and pasta protein for red meat protein. Given the limited number of studies on each outcome of this review, more studies with different aging-related health outcomes and diverse study populations are needed to accumulate more evidence and confirm our findings. These preliminary findings may provide important public health implications as well as recommendations of introducing plant protein-rich sources to replace animal proteins to prevent aging-related diseases, and promote longevity and healthy aging.

Supplementary Materials: The following supporting information can be downloaded at: https: / / www.mdpi.com/article/10.3390/nu14020272/s1, Figure S1: Forest plot of all-cause and causespecific mortality in relation to isocaloric substitution of plant-based protein for animal-based protein. (A) All-cause mortality; (B) total cancer mortality; (C) cardiovascular disease mortality; (D) heart disease mortality; (E) stroke mortality; (F) respiratory disease mortality.

Author Contributions: Conceptualization, H.W., J.Z., T.Z; methodology, J.Z., T.Z.; software, T.Z.; validation, J.Z., T.Z. and G.Y.; writing-original draft preparation, T.Z. and J.Z. writing-review and editing, T.Z., G.Y., J.Z., L.Z., F.L., Y.-M.P., F.K.T. and S.E.S.; supervision, H.W. and X.L.; project administration, H.W. and X.L. All authors have read and agreed to the published version of the manuscript.

Funding: This study was supported by grants from the National Natural Science Foundation of China 82030099 and 81630086, Shanghai Public Health System Construction Three-Year Action Plan GWV-10.1-XK15 and Innovative research team of high-level local universities in Shanghai (to H.W.), Shanghai Pujiang Program 20PJ1409600 and National Natural Science Foundation of China 82103809 (to J.Z.)

Acknowledgments: The authors thank all the authors and participants of each original study included in this review who made this review possible.

Conflicts of Interest: The authors declare no conflict of interest.

\section{References}

1. WHO Organization Ageing and Health. Available online: https://www.who.int/news-room/fact-sheets/detail/ageing-andhealth (accessed on 29 May 2021).

2. Bao, Q.; Pan, J.; Qi, H.; Wang, L.; Qian, H.; Jiang, F.; Shao, Z.; Xu, F.; Tao, Z.; Ma, Q.; et al. Aging and age-related diseases-From endocrine therapy to target therapy. Mol. Cell. Endocrinol. 2014, 394, 115-118. [CrossRef]

3. Bowen, R.L.; Atwood, C.S. Living and dying for sex. A theory of aging based on the modulation of cell cycle signaling by reproductive hormones. Gerontology 2004, 50, 265-290. [CrossRef]

4. Chou, Y.-H.; Chen, Y.-M. Aging and Renal Disease: Old Questions for New Challenges. Aging Dis. 2021, 12, 515-528. [CrossRef] [PubMed]

5. Franceschi, C.; Garagnani, P.; Morsiani, C.; Conte, M.; Santoro, A.; Grignolio, A.; Monti, D.; Capri, M.; Salvioli, S. The Continuum of Aging and Age-Related Diseases: Common Mechanisms but Different Rates. Front. Med. 2018, 5, 61. [CrossRef] [PubMed] 
6. St-Onge, M.-P.; Gallagher, D. Body composition changes with aging: The cause or the result of alterations in metabolic rate and macronutrient oxidation? Nutrition 2010, 26, 152-155. [CrossRef]

7. Ortolá, R.; Struijk, E.A.; García-Esquinas, E.; Rodríguez-Artalejo, F.; Lopez-Garcia, E. Changes in Dietary Intake of Animal and Vegetable Protein and Unhealthy Aging. Am. J. Med. 2020, 133, 231-239. [CrossRef]

8. Rutherfurd-Markwick, K.J. Food proteins as a source of bioactive peptides with diverse functions. Br. J. Nutr. 2012,108 (Suppl. S2), S149-S157. [CrossRef] [PubMed]

9. Santesso, N.; Akl, E.A.; Bianchi, M.; Mente, A.; Mustafa, R.; Heels-Ansdell, D.; Schünemann, H.J. Effects of higher- versus lower-protein diets on health outcomes: A systematic review and meta-analysis. Eur. J. Clin. Nutr. 2012, 66, 780-788. [CrossRef] [PubMed]

10. Song, M.; Fung, T.T.; Hu, F.B.; Willett, W.C.; Longo, V.D.; Chan, A.T.; Giovannucci, E.L. Association of Animal and Plant Protein Intake With All-Cause and Cause-Specific Mortality. JAMA Intern. Med. 2016, 176, 1453-1463. [CrossRef] [PubMed]

11. Wycherley, T.P.; Moran, L.J.; Clifton, P.M.; Noakes, M.; Brinkworth, G.D. Effects of energy-restricted high-protein, low-fat compared with standard-protein, low-fat diets: A meta-analysis of randomized controlled trials. Am. J. Clin. Nutr. 2012, 96, 1281-1298. [CrossRef]

12. Guasch-Ferré, M.; Satija, A.; Blondin, S.A.; Janiszewski, M.; Emlen, E.; O'Connor, L.E.; Campbell, W.W.; Hu, F.B.; Willett, W.C.; Stampfer, M.J. Meta-Analysis of Randomized Controlled Trials of Red Meat Consumption in Comparison With Various Comparison Diets on Cardiovascular Risk Factors. Circulation 2019, 139, 1828-1845. [CrossRef] [PubMed]

13. Schlesinger, S.; Neuenschwander, M.; Schwedhelm, C.; Hoffmann, G.; Bechthold, A.; Boeing, H.; Schwingshackl, L. Food Groups and Risk of Overweight, Obesity, and Weight Gain: A Systematic Review and Dose-Response Meta-Analysis of Prospective Studies. Adv. Nutr. 2019, 10, 205-218. [CrossRef] [PubMed]

14. Qi, X.-X.; Shen, P. Associations of dietary protein intake with all-cause, cardiovascular disease, and cancer mortality: A systematic review and meta-analysis of cohort studies. Nutr. Metab. Cardiovasc. Dis. 2020, 30, 1094-1105. [CrossRef] [PubMed]

15. Abete, I.; Romaguera, D.; Vieira, A.R.; de Munain, A.L.; Norat, T. Association between total, processed, red and white meat consumption and all-cause, CVD and IHD mortality: A meta-analysis of cohort studies. Br. J. Nutr. 2014, 112, 762-775. [CrossRef] [PubMed]

16. Bernstein, A.M.; Pan, A.; Rexrode, K.M.; Stampfer, M.; Hu, F.B.; Mozaffarian, D.; Willett, W.C. Dietary protein sources and the risk of stroke in men and women. Stroke 2012, 43, 637-644. [CrossRef]

17. Chen, Z.; Glisic, M.; Song, M.; Aliahmad, H.A.; Zhang, X.; Moumdjian, A.C.; Gonzalez-Jaramillo, V.; van der Schaft, N.; Bramer W.M.; Ikram, M.A.; et al. Dietary protein intake and all-cause and cause-specific mortality: Results from the Rotterdam Study and a meta-analysis of prospective cohort studies. Eur. J. Epidemiol. 2020, 35, 411-429. [CrossRef]

18. Kramer, H. Diet and Chronic Kidney Disease. Adv. Nutr. 2019, 10, S367-S379. [CrossRef]

19. Turesky, R.J. Mechanistic Evidence for Red Meat and Processed Meat Intake and Cancer Risk: A Follow-up on the International Agency for Research on Cancer Evaluation of 2015. Chimia 2018, 72, 718-724. [CrossRef]

20. Fan, M.; Li, Y.; Wang, C.; Mao, Z.; Zhou, W.; Zhang, L.; Yang, X.; Cui, S.; Li, L. Dietary Protein Consumption and the Risk of Type 2 Diabetes: ADose-Response Meta-Analysis of Prospective Studies. Nutrients 2019, 11, 2783. [CrossRef]

21. Neuenschwander, M.; Ballon, A.; Weber, K.S.; Norat, T.; Aune, D.; Schwingshackl, L.; Schlesinger, S. Role of diet in type 2 diabetes incidence: Umbrella review of meta-analyses of prospective observational studies. BMJ 2019, 366, 12368. [CrossRef]

22. Schwingshackl, L.; Schwedhelm, C.; Hoffmann, G.; Lampousi, A.-M.; Knüppel, S.; Iqbal, K.; Bechthold, A.; Schlesinger, S.; Boeing, H. Food groups and risk of all-cause mortality: A systematic review and meta-analysis of prospective studies. Am. J. Clin. Nutr. 2017, 105, 1462-1473. [CrossRef]

23. Ahnen, R.T.; Jonnalagadda, S.S.; Slavin, J.L. Role of plant protein in nutrition, wellness, and health. Nutr. Rev. 2019, 77, 735-747. [CrossRef]

24. Elliott, P.; Stamler, J.; Dyer, A.R.; Appel, L.; Dennis, B.; Kesteloot, H.; Ueshima, H.; Okayama, A.; Chan, Q.; Garside, D.B.; et al Association between protein intake and blood pressure: The INTERMAP Study. Arch. Intern. Med. 2006, 166, 79-87. [CrossRef]

25. Naghshi, S.; Sadeghi, O.; Willett, W.C.; Esmaillzadeh, A. Dietary intake of total, animal, and plant proteins and risk of all cause, cardiovascular, and cancer mortality: Systematic review and dose-response meta-analysis of prospective cohort studies. BMJ 2020, 370, m2412. [CrossRef] [PubMed]

26. Wu, J.; Zeng, R.; Huang, J.; Li, X.; Zhang, J.; Ho, J.C.; Zheng, Y. Dietary Protein Sources and Incidence of Breast Cancer: A Dose-Response Meta-Analysis of Prospective Studies. Nutrients 2016, 8, 730. [CrossRef] [PubMed]

27. Zhan, S.; Ho, S.C. Meta-analysis of the effects of soy protein containing isoflavones on the lipid profile. Am. J. Clin. Nutr. 2005, 81, 397-408. [CrossRef]

28. Song, M.; Giovannucci, E. Substitution analysis in nutritional epidemiology: Proceed with caution. Eur. J. Epidemiol. 2018, 33, 137-140. [CrossRef]

29. Budhathoki, S.; Sawada, N.; Iwasaki, M.; Yamaji, T.; Goto, A.; Kotemori, A.; Ishihara, J.; Takachi, R.; Charvat, H.; Mizoue, T.; et al. Association of Animal and Plant Protein Intake With All-Cause and Cause-Specific Mortality in a Japanese Cohort. JAMA Intern. Med. 2019, 179, 1509-1518. [CrossRef]

30. Huang, J.; Liao, L.M.; Weinstein, S.J.; Sinha, R.; Graubard, B.I.; Albanes, D. Association Between Plant and Animal Protein Intake and Overall and Cause-Specific Mortality. JAMA Intern. Med. 2020, 180, 1173-1184. [CrossRef] 
31. Kelemen, L.E.; Kushi, L.H.; Jacobs, D.R., Jr.; Cerhan, J.R. Associations of dietary protein with disease and mortality in a prospective study of postmenopausal women. Am. J. Epidemiol. 2005, 161, 239-249. [CrossRef] [PubMed]

32. Liao, L.M.; Loftfield, E.; Etemadi, A.; Graubard, B.I.; Sinha, R. Substitution of dietary protein sources in relation to colorectal cancer risk in the NIH-AARP cohort study. Cancer Causes Control 2019, 30, 1127-1135. [CrossRef] [PubMed]

33. Malik, V.S.; Li, Y.; Tobias, D.K.; Pan, A.; Hu, F.B. Dietary Protein Intake and Risk of Type 2 Diabetes in US Men and Women. Am. J. Epidemiol. 2016, 183, 715-728. [CrossRef] [PubMed]

34. Montiel-Rojas, D.; Nilsson, A.; Santoro, A.; Bazzocchi, A.; de Groot, L.; Feskens, E.J.M.; Berendsen, A.A.M.; Madej, D.; Kaluza, J.; Pietruszka, B.; et al. Fighting Sarcopenia in Ageing European Adults: The Importance of the Amount and Source of Dietary Proteins. Nutrients 2020, 12, 3601. [CrossRef] [PubMed]

35. Sun, Y.; Liu, B.; Snetselaar, L.G.; Wallace, R.B.; Shadyab, A.H.; Kroenke, C.H.; Haring, B.; Howard, B.V.; Shikany, J.M.; Valdiviezo, C.; et al. Association of Major Dietary Protein Sources With All-Cause and Cause-Specific Mortality: Prospective Cohort Study. J. Am. Heart Assoc. 2021, 10, e015553. [CrossRef] [PubMed]

36. van Baak, M.A.; Larsen, T.M.; Jebb, S.A.; Martinez, A.; Saris, W.H.M.; Handjieva-Darlenska, T.; Kafatos, A.; Pfeiffer, A.F.H.; Kunešová, M.; Astrup, A. Dietary Intake of Protein from Different Sources and Weight Regain, Changes in Body Composition and Cardiometabolic Risk Factors after Weight Loss: The DIOGenes Study. Nutrients 2017, 9, 1326. [CrossRef]

37. Altorf-Van Der Kuil, W.; Engberink, M.F.; Ijpma, I.; Verberne, L.D.M.; Toeller, M.; Chaturvedi, N.; Fuller, J.H.; Soedamah-Muthu, S.S. Protein intake in relation to risk of hypertension and microalbuminuria in patients with type 1 diabetes: The EURODIAB Prospective Complications Study. J. Hypertens. 2013, 31, 1151-1159. [CrossRef]

38. Oosterwijk, M.M.; Soedamah-Muthu, S.S.; Geleijnse, J.M.; Bakker, S.J.L.; Navis, G.; Binnenmars, S.H.; Gant, C.M.; Laverman, G.D. High Dietary Intake of Vegetable Protein Is Associated With Lower Prevalence of Renal Function Impairment: Results of the Dutch DIALECT-1 Cohort. Kidney Int. Rep. 2019, 4, 710-719. [CrossRef]

39. Moher, D.; Liberati, A.; Tetzlaff, J.; Altman, D.G. Preferred reporting items for systematic reviews and meta-analyses: The PRISMA statement. BMJ 2009, 339, b2535. [CrossRef]

40. Wells, G.A.; Shea, B.; O'Connel, D.; Peterson, J.; Welch, V.; Losos, M.; Tugwell, P. The Newcastle-Ottawa Scale (NOS) for Assessing the Quality of Nonrandomised Studies in Meta-Analyses. Available online: http://www.ohri.ca/programs/clinical_ epidemiology/oxford.asp (accessed on 31 May 2021).

41. Levey, A.S.; Eckardt, K.-U.; Tsukamoto, Y.; Levin, A.; Coresh, J.; Rossert, J.; De Zeeuw, D.; Hostetter, T.H.; Lameire, N.; Eknoyan, G. Definition and classification of chronic kidney disease: A position statement from Kidney Disease: Improving Global Outcomes (KDIGO). Kidney Int. 2005, 67, 2089-2100. [CrossRef]

42. Kokubo, Y.; Iso, H.; Ishihara, J.; Okada, K.; Inoue, M.; Tsugane, S. Association of dietary intake of soy, beans, and isoflavones with risk of cerebral and myocardial infarctions in Japanese populations: The Japan Public Health Center-based (JPHC) study cohort I. Circulation 2007, 116, 2553-2562. [CrossRef]

43. Pan, A.; Franco, O.H.; Ye, J.; Demark-Wahnefried, W.; Ye, X.; Yu, Z.; Li, H.; Lin, X. Soy protein intake has sex-specific effects on the risk of metabolic syndrome in middle-aged and elderly Chinese. J. Nutr. 2008, 138, 2413-2421. [CrossRef]

44. Jenkins, D.J.; Kendall, C.W.; Connelly, P.W.; Jackson, C.J.; Parker, T.; Faulkner, D.; Vidgen, E. Effects of high- and low-isoflavone (phytoestrogen) soy foods on inflammatory biomarkers and proinflammatory cytokines in middle-aged men and women. Metabolism 2002, 51, 919-924. [CrossRef] [PubMed]

45. Bhupathy, P.; Haines, C.D.; Leinwand, L.A. Influence of sex hormones and phytoestrogens on heart disease in men and women. Womens Health 2010, 6, 77-95. [CrossRef] [PubMed]

46. Aune, D.; Keum, N.; Giovannucci, E.; Fadnes, L.T.; Boffetta, P.; Greenwood, D.C.; Tonstad, S.; Vatten, L.J.; Riboli, E.; Norat, T. Whole grain consumption and risk of cardiovascular disease, cancer, and all cause and cause specific mortality: Systematic review and dose-response meta-analysis of prospective studies. BMJ 2016, 353, i2716. [CrossRef]

47. Wang, X.; Lin, X.; Ouyang, Y.Y.; Liu, J.; Zhao, G.; Pan, A.; Hu, F.B. Red and processed meat consumption and mortality: Dose-response meta-analysis of prospective cohort studies. Public Health Nutr 2016, 19, 893-905. [CrossRef]

48. Krittanawong, C.; Narasimhan, B.; Wang, Z.; Virk, H.U.H.; Farrell, A.M.; Zhang, H.; Tang, W.H.W. Association Between Egg Consumption and Risk of Cardiovascular Outcomes: A Systematic Review and Meta-Analysis. Am. J. Med. 2021, 134, 76-83. [CrossRef]

49. Drouin-Chartier, J.-P.; Chen, S.; Li, Y.; Schwab, A.L.; Stampfer, M.J.; Sacks, F.M.; Rosner, B.; Willett, W.C.; Hu, F.B.; Bhupathiraju, S.N. Egg consumption and risk of cardiovascular disease: Three large prospective US cohort studies, systematic review, and updated meta-analysis. BMJ 2020, 368, m513. [CrossRef]

50. Schwingshackl, L.; Schwedhelm, C.; Hoffmann, G.; Knüppel, S.; Preterre, A.L.; Iqbal, K.; Bechthold, A.; De Henauw, S.; Michels, N.; Devleesschauwer, B.; et al. Food groups and risk of colorectal cancer. Int. J. Cancer 2018, 142, 1748-1758. [CrossRef]

51. Schwingshackl, L.; Hoffmann, G.; Lampousi, A.-M.; Knüppel, S.; Iqbal, K.; Schwedhelm, C.; Bechthold, A.; Schlesinger, S.; Boeing, $\mathrm{H}$. Food groups and risk of type 2 diabetes mellitus: A systematic review and meta-analysis of prospective studies. Eur. J. Epidemiol. 2017, 32, 363-375. [CrossRef] [PubMed]

52. Li, S.S.; Mejia, S.B.; Lytvyn, L.; Stewart, S.E.; Viguiliouk, E.; Ha, V.; de Souza, R.J.; Leiter, L.A.; Kendall, C.W.C.; Jenkins, D.J.A.; et al. Effect of Plant Protein on Blood Lipids: A Systematic Review and Meta-Analysis of Randomized Controlled Trials. J. Am. Heart Assoc. 2017, 6. [CrossRef] 
53. Viguiliouk, E.; Stewart, S.E.; Jayalath, V.H.; Ng, A.P.; Mirrahimi, A.; de Souza, R.J.; Hanley, A.J.; Bazinet, R.P.; Mejia, S.B.; Leiter, L.A.; et al. Effect of Replacing Animal Protein with Plant Protein on Glycemic Control in Diabetes: A Systematic Review and Meta-Analysis of Randomized Controlled Trials. Nutrients 2015, 7, 9804-9824. [CrossRef] [PubMed]

54. Richter, C.K.; Skulas-Ray, A.C.; Champagne, C.M.; Kris-Etherton, P.M. Plant protein and animal proteins: Do they differentially affect cardiovascular disease risk? Adv. Nutr. 2015, 6, 712-728. [CrossRef]

55. Wang, T.J.; Larson, M.G.; Vasan, R.S.; Cheng, S.; Rhee, E.P.; McCabe, E.; Lewis, G.D.; Fox, C.S.; Jacques, P.F.; Fernandez, C.; et al. Metabolite profiles and the risk of developing diabetes. Nat. Med. 2011, 17, 448-453. [CrossRef]

56. Domingo, J.L.; Nadal, M. Carcinogenicity of consumption of red meat and processed meat: A review of scientific news since the IARC decision. Food Chem. Toxicol. Int. J. Publ. Br. Ind. Biol. Res. Assoc. 2017, 105, 256-261. [CrossRef]

57. Etemadi, A.; Sinha, R.; Ward, M.H.; Graubard, B.I.; Inoue-Choi, M.; Dawsey, S.M.; Abnet, C.C. Mortality from different causes associated with meat, heme iron, nitrates, and nitrites in the NIH-AARP Diet and Health Study: Population based cohort study. BMJ 2017, 357, j1957. [CrossRef] [PubMed]

58. Feskens, E.J.; Sluik, D.; van Woudenbergh, G.J. Meat consumption, diabetes, and its complications. Curr. Diabetes Rep. 2013, 13, 298-306. [CrossRef]

59. Hollænder, P.L.; Ross, A.B.; Kristensen, M. Whole-grain and blood lipid changes in apparently healthy adults: A systematic review and meta-analysis of randomized controlled studies. Am. J. Clin. Nutr. 2015, 102, 556-572. [CrossRef]

60. McKeown, N.M.; Meigs, J.B.; Liu, S.; Wilson, P.W.; Jacques, P.F. Whole-grain intake is favorably associated with metabolic risk factors for type 2 diabetes and cardiovascular disease in the Framingham Offspring Study. Am. J. Clin. Nutr. 2002, 76, 390-398. [CrossRef]

61. Mariotti, F.; Huneau, J.-F. Plant and Animal Protein Intakes Are Differentially Associated with Large Clusters of Nutrient Intake that May Explain Part of Their Complex Relation with CVD Risk. Adv. Nutr. 2016, 7, 559-560. [CrossRef]

62. Jennings, A.; MacGregor, A.; Welch, A.; Chowienczyk, P.; Spector, T.; Cassidy, A. Amino Acid Intakes Are Inversely Associated with Arterial Stiffness and Central Blood Pressure in Women. J. Nutr. 2015, 145, 2130-2138. [CrossRef] [PubMed]

63. Windey, K.; De Preter, V.; Verbeke, K. Relevance of protein fermentation to gut health. Mol. Nutr. Food Res. 2012, 56, 184-196. [CrossRef] [PubMed]

64. Wang, Z.; Klipfell, E.; Bennett, B.J.; Koeth, R.; Levison, B.S.; Dugar, B.; Feldstein, A.E.; Britt, E.B.; Fu, X.; Chung, Y.-M.; et al. Gut flora metabolism of phosphatidylcholine promotes cardiovascular disease. Nature 2011, 472, 57-63. [CrossRef]

65. Chan, R.; Leung, J.; Woo, J.; Kwok, T. Associations of dietary protein intake on subsequent decline in muscle mass and physical functions over four years in ambulant older Chinese people. J. Nutr. Health Aging 2014, 18, 171-177. [CrossRef] [PubMed]

66. Gardener, H.; Caunca, M.R. Mediterranean Diet in Preventing Neurodegenerative Diseases. Curr. Nutr. Rep. 2018, 7, 10-20. [CrossRef] [PubMed] 